\title{
Safevi Döneminde Avrupa Tarzı Duvar Resimleri: Bir Sanat Tarihi Okuması
}

\author{
Nazanin Davari* \\ Jamshid Hatam**
}

\section{Öz}

Safevi hanedanının en önemli hükümdarlarından biri olan Şah Abbas, İran'ın birleştirilmesini ve güçlenmesini sağlamıştır. $\mathrm{Bu}$ dönemde Avrupa'dan gelen tüccarlar, elçiler, doktorlar v.s, İran Hrıstiyan toplumları ile yakın bir temas kurup sanat ortamını etkilemişlerdir. Safevi Devri'nde İran resim sanatında padişahların da desteği ile yeni bir dönem açılmıştır. Özellikle de kültür ve imar meraklısı Şah Abbas, sanatçıları, bilim insanlarını ve filozofları himayesi altına alıp İran tarihinde kültürel bir devrim yapmıştır. Bu çalışmada Avrupa anlayışı ile yapılımış duvar resimleri bağlamında Safevilerin başkenti İsfahan'da bulunan ve bu tarz ile meydana çıkmış duvar resimleri tartışılmışıtr. Avrupa tarzı duvar resimlerinin çoğu Çihil Sütun sarayında yapılmış olmasına rağmen Sokiyas Köşkü ve Serder-i Kayseriye gibi başka yapıtlarda da bu tarz resimlere rastlanmıştır. Bu tarz resimler duvar üzerinden başka keten ve kağıt üzerine de yapılmıştır. Sarayların içinde yapıtın raporları mevcut olmasına rağmen bu eserlerin kimin tarafindan yapıldığı belgelenememiştir.

Anahtar Kelimeler: Safevi, Şah Abbas, Çihil Sütun Sarayı, Duvar Resmi, Avrupa Tarzı Resimler, Ressamlar

\footnotetext{
* Ankara Üniversitesi, Sanat Tarihi Bölümü, Doktora Öğrencisi. Tahran Azad Sanat Üniversitesi, Fotoğrafçılık Bölümü, nazanin_davari1980@yahoo.com

** Hacettepe Üniversitesi, Sanat Tarihi Bölümü, Doktora Ögrrencisi, Tahran Azad Sanat Üniversitesi Fotoğrafçılık Bölüm Öğretim Üyesi. jamshidhatam@yahoo.com
} 


\title{
European Style Wall Paintings in the Safavid Period: An Art History Reading
}

\author{
Nazanin Davari* \\ Jamshid Hatam**
}

\begin{abstract}
Shah Abbas, one of the most important monarchs of the Safavid dynasty, provided the consolidation and strengthening of Iran. The artistic environment has also been influenced by close contacts with traders, ambassadors, doctors, etc., Iranian Christian communities from Europe. During the Safavid era, a new era was opened with the support of the sultans in Iranian painting art. Cultural and reconsctruction enthusiast, Shah Abbas, under the auspices of artists, scientists and philosophers, made a cultural revolution in Iran's history. In this study, wall paintings which is located in Isfahan, the capital of the Safavids in the context of wall paintings made with European understanding, are discussed. Although most of the European style wall paintings were made in the Çihil Sutun palace, such paintings were found in other places such as Sokiyas Pavilion and Serdar-i Kayseriye. These kinds of paintings were made on the wall, sacks and paper. The reports of the work in the palaces were not documented by anyone.
\end{abstract}

Keywords: Safavid, Shah Abbas, Chehel Sutun Palace, Wall painting, European paintings, Painters.

* PhD Student, Department of Art History, Ankara University, Tehran Azad Art University, Photography Department. nazanin_davari1980@yahoo.com

** PhD Student, Department of Art History, Hacettepe University, Tehran Azad Art University Photography Department Faculty Member. jamshidhatam@yahoo.com 


\section{Giriş}

Safevi Devleti, Şeyh Haydar tarafından 1469-1487'de kurulmuştur. Oğlu Şah İsmail kendisinden sonra tahta geçip Erdebil'den ayrılmış; Tebriz'i başkent yapmış ve Şii mezhebini de devletin resmi dini ilan etmiştir. ${ }^{1}$ 1501-1523 yılları arasında tahtta oturan Şah İsmail zamanının çoğunu Osmanlı Devleti ile savaşmakla geçirmiş ve 1514 yılında meşhur Çaldıran Savaşı'nda Osmanlılara yenilmiştir. Şah İsmail'in ölümünden sonra oğlu Tahmasb (1523-1576) 10 yaşında iken Safevi Şahı olmuştur. Şah Tahmasb da kendi zamanında Özbeklerle ve Osmanlılarla savaşmak zorunda kalmıştır. ${ }^{2} \mathrm{Bu}$ savaşlar Safevi Devletinin hazinelerinin boşalmasına sebep olmuştur. Bu yüzden başkenti Tebriz'den, Kazvin şehrine taşıyı Osmanlıların hücumlarından uzaklaşmak gereğini hissetmişlerdir. ${ }^{3}$

Şah Tahmasb'dan sonra II. Şah İsmail 1576-1577 (955-956) bir y1l Safevi padişahı olarak başa geçmiştir. Safevi Devleti'nin en büyük hükümdarlarından biri olan Şah Abbas (1587-1629 (966-1007 h.ş)) tahta çıktığında içte ve dışta çeşitli meselelerle karşı karşıya kalmıştır. Şah Abbas Safevi Devleti'ni yıkılmak tehlikesinden kurtardığı gibi ona en parlak ve kudretli devrini de yaşatmıştır. ${ }^{4}$

Şah Abbas (Res.1) 1597-8 y1lında devlet merkezini Kazvin'den İsfahan'a naklederek orada geniş çapta imar faaliyetlerine girişmiştir. İsfahan'da büyük bir saray, cami, mescit, medrese, hastane, hamamlar, çarşılar ve kervansaraylar inşa ettirmiştir. Yine İsfahan'da Çehar Bağ caddesini oluşturmuş ve şehrin içinden geçen Zâyende Rud Irmağı üzerinde bir köprü yaptırmıştır. Şah Abbas yabancı uzmanlardan yardım alarak orduyu düzenlemiş ve kuvvetlendirmiştir.

Şah Abbas devri ticari, politik ve askeri başarılar yanında çinicilik, seramik, dokumacılık, halıcılık, kuyumculuk, maden işçiliği, hat, minyatür, resim, tezhip ve ciltçilik gibi devrinin her türlü güzel sanatları büyük bir

“Haydar-mirza-safavi," iranicaonline, Nisan 20, 2015, http://www.iranicaonline.org/ articles/haydar-mirza-safavi.

2 Lutfullah Honarfar, Gencine-1 Asar-1 Tarih-1 İsfahan, (Tahran/İsfahan Üniversitesi, 1966), 7.

3 Honarfar, Gencine-1 Asar-1 Tarih-1 İsfahan, 8.

4 Cihat Aydoğmuşoğlu, “Şah Abbas (1587-1629) Devrinde İran’da Sosyal ve Kültürel Hayat", Türk Dünyası İncelemeleri Dergisi / Journal of Turkish World Studies, no. XI/2 (April 2011) :261-262. 
gelişme göstermiştir. Aynı şekilde Safevilerin en büyük rakibi olan Osmanl1larla ihtilaf halindeki Avrupa ülkeleri ile kurduğu olumlu siyasi ilişkilerin sonucu olarak bu ülkelerle kültürel alışveriş de onun döneminde büyük bir ivme göstermiştir. Zira Avrupa ülkelerinin siyasi ve askeri başarılarının meydana getirdiği üstünlük yanında bilhassa halı ticareti sayesinde kurulan diyaloglar ve karşılıklı ziyaretler, onların kültür ve sanat alanlarında da ileri olduğu duygusu uyandırdığından İran resim sanatında Avrupai tarzda değişimler başlamıştır. Ticaret yolları üzerinde yer alan ve önemli bir merkez olan İsfahan'ın başkent oluşu ile birlikte kent, diplomasinin ve ticaretin de önemli bir merkezi haline gelmiştir. Avrupalı sanat eğilimlerinin İsfahan'daki yeni sarayda görülmeye başlaması şüphesiz şehrin bu diş etkilere açık konumundan kaynaklanmıştır. Bu arada uzun yıllar devam eden savaşların meydana getirdiği psikolojik yorgunluk sonunda zevke ve eğlenceye yöneliş çoğu ülkeler gibi Safeviler için de kaçınılmaz olmuştu. Aynı şekilde, Doğuda Babür ve Timur Hanlığı ve batıda Osmanlı gibi güçlü rakip ülkelerle yaşanan amansız siyasi rekabetin sanata ve mimariye yansımaması da mümkün değildi. Bütün bunların sonucu olarak İsfahan şehri 11. Yüzyıldaki Büyük Selçuklular devrine benzer imar faaliyetleri ile kendini gösterdi ve sonunda İsfahan şehri 17. Yüzyılda bir anda "nısf-1 cihan olarak görülmeye başlandı. Bu gelişmelerde tabii ki Avrupalı ziyaretçilerin, tüccar ve diplomatların sarayın beğenisine ve hâmiliğine yeni anlayışlar taşımasının yanı sıra Şah Abbas döneminde İsfahan'ın dışında Ermeni ahali için oluşturulan Colfa mahallesi ve burada yaşayan Hristiyan hâmilerin de Avrupalı eğilimlerinin hızlanmasında etkin bir rolü olmuştur. ${ }^{5}$

Aydoğmuşoğlu, "Şah Abbas (1587-1629) Devrinde Iran'da sosyal ve Kültürel hayat", 270. 
Resim 1: Şah Abbas Safevi'nin Portresi, “by Esaye Le Gillon, Prague, Dated Safar AH 1013/JUNE-JULY 1604-Portrait of Sinal Shah Kamlu, Ambassador of Shah Abbas I to Emperor Rudolf II", "Shah Abbas", Christies, Google, Erişim tarihi: Ekim 01, 2017, http://www.christies.com/ Shah Abbas.

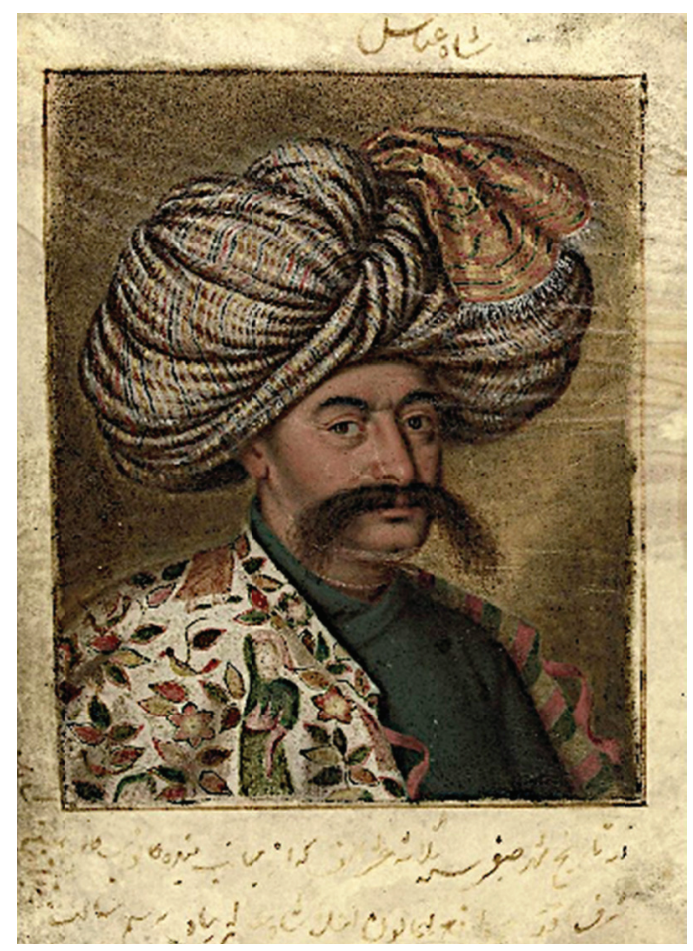

Kaynakların belirttiğine göre Şah Abbas tarafından 1604 (983.h.ş) yılında Kafkasya'dan 100 bine yakın Ermeni göçmen İsfahan'ın Colfa mahallesine yerleştirilmiştir. ${ }^{6}$ Böylece Ermeni-Hristiyan kültürünün ve Avrupai sanat zevklerinin İran'a ulaşması daha kolay olmuştur. Nitekim Ermeni kiliselerinin süslenmesi için İtalyan tarzı figüratif dokumacılık (goblen), perde ve duvar resimlerinin kullanışı yoğunlaşmıştır. Avrupa sanatsal bakış açısı İranlılar için yeni bir ufuk açmış ve sonuç olarak Şah Abbas’ın sarayında İtalyan, Alman ve Hollandalı sanatçılar (ressamlar) çalışmaya başlamışlardır. Daha sonra da Şah’ın desteği ile İranlı öğrenci sanatçılar, Batı

Jalal Sattari, “Alı Kapu duvar resimleri”, Honar va mardom (Sanat ve Toplum) dergisi, 6. Sayı, (Aralık 1986), 63. 
tarzı resim yapmayı öğrenmek için Roma’ya gönderilmişlerdir. Böylelikle Safevi döneminde İran resim tarihi adeta bir dönüm noktası teşkil etmiştir. Böylece Şah Abbas'ın başkent yaptığı İsfahan şehri İran'ın siyasi olduğu kadar sanat ve kültür alanlarında da en önemli şehri olmuştur. Bu devirde minyatür üsluplarındaki Tebriz, Kazvin, Şiraz ve İsfahan ekolleri bunun kanıtıdır. Safevi döneminde minyatür sanatı gelişirken duvar resimleri açısından da parlak bir dönem yaşanmıştır.

Aslında bir ülkenin, başka ülkelerden sanatçı davet ederek ve/veya kendi sanatçılarını başka ülkelere göndererek oraların farklı sanatlarından feyiz alma yoluna gitmesi sadece Safevilere ait bir olay değildir. Bilindiği gibi unun Osmanlılar açısından en meşhur örneği İstanbul'un fethinden sonra yaşanmıştır. İstanbul'u fetheden Osmanlı sultanı II. Mehmed (öl. 1481), Avrupa resim sanatına duyduğu hayranlık sebebiyle Gentile Bellini ve Costanzo da Ferrara gibi meşhur Rönesans sanatçılarını İstanbul'a davet ederek kendi resmini yapmalarını ve burada öğrenci yetiştirmelerini istediği pek meşhurdur. İstanbul'da bu büyük ustalar hem fazla kalmadığı için, hem de II. Mehmed'den sonra gelen II. Bayezid'in (öl. 1512) babasına zıt bir din, devlet ve sanat anlayışı yüzünden Batı tarzı resim sanatı ölü doğmuştur. Oysa İran'daki Rönesans tarzına benzeyen resimler ciddi bir yekûn tutmaktadır. Zira ressamların özellikle İsfahan saraylarında çizdiği tasvirlerde Avrupa üslubu ile Doğu üslubunun (İran ve Babür üslupları) birleştirilmesi yeni bir üslubun ortaya çıktığ görülmektedir.

Safevi duvar resmi bir taraftan devlet adamlarının savaşlarını ve günlük hayatlarını, eğlencelerini yansıtırken, diğer taraftan da halkın yaşantısına 1şık tuttuğu görülmektedir. Aslında duvar resmi deyince, Pompei, Mısır, Çin, antik dönem ya da günümüzdeki duvar resimleri akla gelmektedir. Tarih boyunca her dönemin yaşamını yansıtacak duvar resimleri farklı teknik ustalıklarda ve çok sayıdadır. Eğlenceleri, törenleri, inançları gösteren toplumsal içerikli çalışmalar ayrı bir konudur. İlk örneklerine mağara devrinde rastladığımız duvar resminin serüveni günümüze kadar gelmiştir. Zaman içinde yer ve toplumlara bağlı olarak konu, teknik, malzeme ve plastik yapı açısından değişikliklere uğramıştır. Kimi zaman resim sanatının belirleyicisi olmuş, kimi zaman ikinci plana düşmüş ve hatta kesintilere uğramıştır. Resim yapmanın bilinen gerçeği bireyin kendisini ifade etmesidir. Aslında her yapıt sanatçının yaşadığı dönem hakkında bize ipuçları verir. $\mathrm{Bu}$ özelliğiyle duvar resmi bir taraftan sosyal ve ekonomik yapının diğer 
taraftan da bireylerin psikolojik süreçlerinin tanığı gibidir. Aynı zamanda duvar resimleri gerçekleştirilme aşamasında çağının teknik imkânlarını kullanarak malzemesini de içinde bulunduğu ortama göre belirlemiştir. Duvar resminin uygulaması ister iç ister dış mekanlarda isterse açık alanlarda olsun mimari bir öğe olan duvarda yer alır. Bu zorunlu beraberlik resmi kendiliğinden bir mimari öğe durumuna sokar. Duvar, kemer, kubbe, pencere vb. resmin çizildiği yerler olmuşlardır. $O$ halde resmin aynı anda hem mimari çevreden etkilenmesi, hem de onu etkilemesi son derece doğal bir durumdur. Öncelikle resim, boyut ve form açısından duvara bağımlıdır. Uygulanacak teknik yerine göre seçilmek zorundadır. Bu çalışmada sözü edilen duvar resmi; doğrudan yaşanan gerçekliğin imge olarak aktarımınından farklı olarak tasarlanmış, 1smarlanmış estetik değerlerini taşıyan duvar resimlenmesidir. Bir malzeme olarak "duvar" Safevi dönemindeki Avrupa tarzı duvar resimleri için bir malzeme olarak kullanılmıştır. Bu resimlerin çoğu Rönesans Tarzı ile betimlenmiş fakat Avrupa resimleri ile k1yaslandığında daha basit ve tekniği daha yüzeysel gözükmektedir. Avrupa tarzı duvar resimlerindeki gerçekçilik yoluna giden portrelere, toplumsal yaşam, savaş sahneleri vs. İran'ın resim sanatındaki Avrupa sanat dünyasından ilham aldığını bize aktarmaktadır.

\section{Safevi Döneminde Duvar Resimleri ve Ressamları}

İran'da bulunan en eski duvar resimleri, Dousheh (دوشه) Mağarası'nın kayaları üzerinde ve Lorestan'ın Kohdasht bölgesindeki Mirmallai Vadisi'nde tasvir edilen Neolitik (yaklaşık M.Ö 8000) döneme aittir. Mağaracılar tarafından yaratılmış bu ilkel ve basit resimlerde atlar, keçiler ve köpekler gibi hayvan figürlerinin yanında okçuluk ve savaş sahneleri de tasvir edilmiştir. Resimlerin daha gerçekçi görünebilmesi için de kırmızı, siyah ve hafif sarı renklerin kombinasyonu kullanılmıştır. Profesör Graishman'e göre; "Bu resimler, insanın bir yemek koleksiyoncusu gibi yaşadığı dönemde Lorestan sakinleri tarafından çizilmiştir ve bu dönem, insanlar dağdan aşağı inip mağaralardan dışarı çıkabilme imkanı bulana dek ve vadiler kuruyana kadar geçen binlerce yıl ile bağlantılıdır. Bu resimlerin üslubu daha özenlidir. Yırtıcı hayvanların savaş ve kaçış sahneleri basitçe çizilmişken figürlerin gösterilmesinde ise abartıya kaçılmıştır. Akamenid döneminde, Persepolis'te ana adı «Parseh» olan çok sayıda döşeme ve kabartma olmasına rağmen duvar resmi sanatı adına bir ürün yoktur. 8-13. yüzyıllar ara- 
sına tarihlenen Doğu İslam duvar resimleri, içinde insan tasvirlerinin bile nadir olduğu birkaç örnekle bilinmektedir. Kuzeydoğu İran, Afganistan ve Orta Asya`nın geniş bölgelerinde (8. yüzyılda kabaca büyük Horasan idari bölgesine denk bir bölge) böyle resimli duvarlar Nişabur, Leşker-i Bazar ve Hulbuk gibi şehirlerde görülmektedir. Üstelik halen Metropolitan Müzesi>nde sergilenen bazı parçaların (10-12. yüzyılın) Rey>den geldiği düşünülmektedir".?

Söz konusu Safevi dönemindeki saray ve köşklerde süsleme ve duvar resimleri, Avrupa kiliselerinin izlerini takip etmiştir. Âli Kapu'da bulunan köşklerin ve Çihil Sütun süslemeleri, Şah Abbas ve ondan sonra gelen Şahların dönemine ait örneklerdir. Bununla beraber az sayıda bulunmakla birlikte Safevi dönemi yapıtlarında kullanılan süslemeler ve resimler Selçuklular, İlhanlılar ve Timur döneminde (Herat ve Tebriz okulu) kitaplarıyla benzerlikler göstermiştir (Varka ve Gülşah gibi). Böylece Safevi döneminde, süsleme sanatı, İsfahan'da en parlak dönemini yaşamıştır. ${ }^{8}$ Safevi döneminde İsfahan'da yaşayan meşhur ressam Rıza Abbasi, Çihil Sütun ve Âli Kapu'nun duvar resimlerinden başka pek çok kitap süslemeleri de yapmıştır. Mektebindeki öğrencileri de kendisine yardım etmişlerdir. Rıza Abbasi'nin kendine has üslubu, İran'da Rıza Abbasi mektebi diye anılmasina sebep olmuştur.

Rönesans sanatının gerçekçiliği ve hümanist görünüşleri, Safevi döneminde İran sanatını etkilemiştir. Ama bu etkileşim sürecinde sadece yüzeysel gerçekçilikle yetinilmemiştir. Bu etkileşim aynı zamanda İran resim felsefe ve üslubunu da yönlendirip gerçeklikle hayal arasında bir dünya yaratmıştır. Muhammed Zaman ve Ali Goli Cobbedar'ın çalışmaları bu üslupla yapılan resimlerin en güzel örneklerindendir. Aslında İran'ın tarihine bakacak olursak bütün devirlerde İran'ın kültür ve sanatı başka medeniyetlerle etkileşim halinde olmuş fakat zaman içinde yeni bir üslup ve düşünce de ortaya koymuştur. İran Batı-Doğu ve Uzak Doğuya bağlanan bir coğrafyadadır. Dolayısıyla Batı ve Doğu kültüründen etkilenmesi oldukça normal sayılmaktadır. Örneğin; İlhanlı döneminde Uzak Doğu ve Orta Asya'dan gelen minyatür tasvirlerinin Pers döneminin resimleri ile (Mani resimleri

A. U. Pope, ed., A Survey of Persian Art, 1-6. (london and New York: Oxford University Press, 1939), vol. 5, res. 554, A ve B.

8 Gholamali Hatam, Honar ve Temeddünü İslami, (Payam Nur Üneversitesi Yayınları), Tahran, II cilt, 2005, 61. 
gibi) karışması İran edebiyat ve felsefesinde yeni bir üslup (Tebriz, Hrat, Şiraz ve Safevi ekolü gibi) ortaya çıkarmıştır.

Görüldüğü üzere Safevi döneminden önce duvar resim sanatı geleneği yaşanmamıştır. Safevi döneminde ilk duvar tasviri Aka Sadik/ Sadik El-Vad atfı olan yağlı boya tekniği ile yapılmıştır (Res. 2). Bu dönemde yapılan duvar resimlerinin çoğunun sanatçısı belli değildir. Ancak Safevi döneminde yapılan kitap tasvirleri ve duvar resimlerinin üsluplarının benzerliklerinden yola çıkılarak duvar ressamlarının bulunması mümkündür.

Dolayısıyla Safevi döneminin duvar resimleri, bilhassa Şah Abbas'ın dönemine ait olan resimlerin çoğu İran üslubuna ait İsfahan ekolünün üslubunu gösterir. Bu eserler Rıza Abbasi’nin nezaretinde ve öğrencilerinin de çalışmalarıyla ortaya çıkmışlardır.

Genel olarak, Safevi döneminde meşhur olan ressamları dört gruba ayırabiliriz:

1. 16. Yüzy1lında, yaşayan ve bu devir ressamları: I. Şah Abbas dönemi: Siyavuş Gorji, Sadığı Beyg, Ağa Rıza, Rıza Abbasi.

2. 17. Yüzyılın birinci yarısında, yaşayan sanatçılar: Muhammed Kasım, Moin Mosevver, Afzel el Hüseyni, Şefi-i Abbasi, Muhammed Yusuf, Muhammed Ali. Bu kişiler Şah Abbas döneminde öğrenci olup zamanın üstatlarından bilhassa Rıza Abbasi'den ders almışlardır. Bu kişiler kendi dönemlerinde üstad olarak faaliyet göstermişlerdir. 
Res. 2: Çihil Sütun sarayı. Çaldıran savaşı, Aka Sadik/ Sadik El-Vad atıflıdır. "Chaldıran”, Flicker Photos, Erişim tarihi: Şubat 05, 2017, http://www.flickr. com/photos/youngrobv/1803476053/.

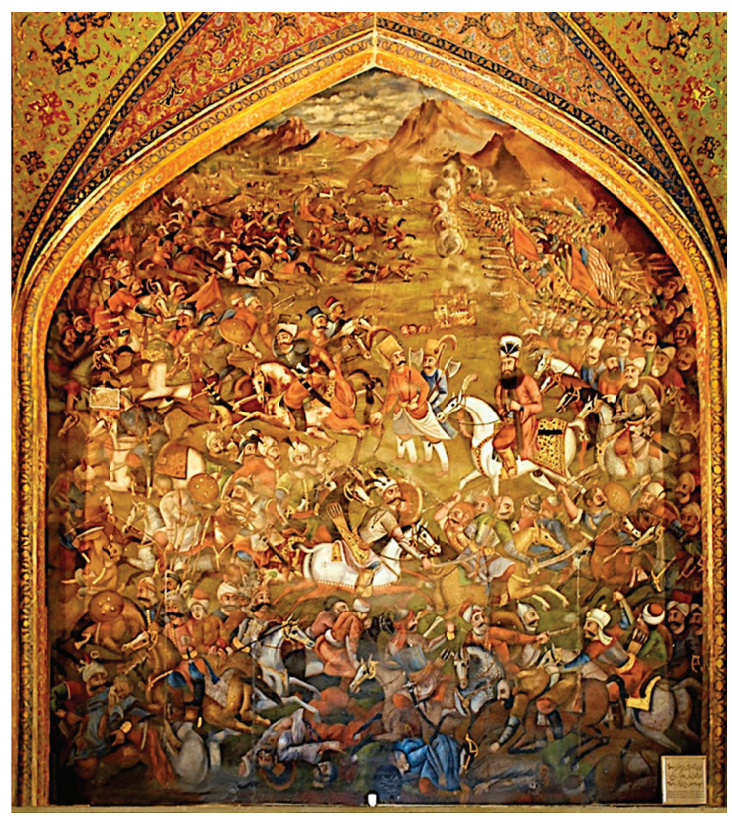

3. 17. yüzyılın ikinci yarısı ve sonlarına doğru ortaya çıkan sanatçılar: Avrupa tarzındaki resimlere hayran kalarak, bu üslubu taklit eden sanatçılardır: Muhammed Zaman, Ali Kulu Cebbedar, Bahram Sofrekeş bunların en güzel örnekleridir.

4. Yabancı uyruklu ressamlar: Başka bir vazife veya amaç için İran'da bulunurken ressamlık da yapmışlardır (Doktor, Hollandalı tüccarlar, elçi v.s). Hristiyan Ermeniler de Hintli sanatçılar gibi Şah Abbas döneminde sarayda çalışmışlardır ${ }^{9}$.

9 Hollandalı ressamlar: Lokar (Hendrich Boud Ewisin Van Lockhorst), Flander ressamlar: Angel (Philip Van Angel) Hasselt (İan Van Hasselt), Ermeni ressam: Minas ve Hindistanlı ressam: Vishnodas. 


\subsection{Safevi Devrinde Avrupa Tarzı ile Resim Yapan İran'lı Ressamlar}

\subsubsection{Muhammed Zaman}

Şah Abbas zamanında yaşadı̆̆ bilinmekle birlikte doğum ve ölüm tarihleri bilinmeyen Muhammed Zaman'in bu şah tarafindan Roma'ya İtalyan resim sanatını öğrenmek için gönderildiği söylenmektedir. Hermitage'da muhafaza edilen bir kalem kutusu üzerinde kendisi gibi ressam olan oğlu Muhammed Ali İbn Muhammed Zaman'a ait süslemelerde imza yerinde "Merhum Muhammed Zaman'ın oğlu Muhammed Ali" yazısına ve "1701" tarihine bakılırsa, ressamın o tarihte artık hayatta olmadığı anlaşılmaktadir. ${ }^{10}$

Ressamımızın resimlerinde çok belli olacak şekilde Avrupaî tarzına rağmen hayatına dair bilgi yetersizliği onun isminin etrafinda birtakım söylentilerin ve varsayımların zuhur etmesine olanak vermiştir. Böyle bir söylenceye göre Muhammed Zaman İtalya'da bulunduğu sırada Hristiyan olmuş ve ülkesine "Paolo Zaman" adıyla dönmüştür. Fakat İslâmî hassasiyetin çok yoğun yaşandığ o devirde Müslüman bir kimsenin Hristiyan olup Paolo ismiyle ülkesine dönerek, aynı zamanda dinî lider konumundaki şahın mahiyetinde sanat icra etmesi pek mantıkl gözükmemektedir. Belki de bu iddia, onun Batı tarzı resim yapmasını karşı çıkan muhafazakâr nakkaşların ve onu çekemeyen kimselerin ürünüdür. Ya da sanatçı Ermeni kökenlidir. Nitekim Rus sanat tarihi araştırmacısı A. İvanov 17-18. yüzyıllarda İan'da "Muhammed Zaman" adıyla ünlenmiş on dokuz kişiden hiçbirinin Italya'ya gitmemiş olduğunu tespit etmiştir. ${ }^{11}$ Yenilikleri takip ve yüksek ve orijinal bir sanat elde etme çabasında olduğunu bildiğimiz Şah Abbas'ın Avrupa'ya öğrenci göndermiş olduğunu düşünmek hiç de yadırganacak bir durum değildir. Fakat bunu kanıtlayacak bir belgeye sahip olmadığımız da diğer bir gerçektir. Yine onun, klasik İslam minyatür anlayışının dışına çıkarak Batı tarzında resimler yaptığı da eserlerinden açıkça belli olmaktadir.

Iran'da bez üzerine yağllboya resim yapan ilk sanatkâr olduğu kabul edilen. Muhammed Zaman; Şah Abbas (1532-1567), Süleyman (1667-1694) ve Sultan Hüseyin'in (1694-1722) saray ressamı olmuştur. 17. yüzyılın

10 "Muhammed Zaman”, Wikipedia, Erişim Tarihi: Ocak 13, 2016, http://tr.wikipedia. org/wiki/Muhammed Zaman/.

11 Wikipedia, "Muhammed Zaman". 
ikinci yarısında Safevi resminde görülen Avrupa tarzının en önemli temsilcilerindendir, Muhammed Zaman klasik minyatür anlayışında resimler de yapmakla birlikte bazı eserlerinde devrinin Avrupa resim anlayışına uygun olarak ışı-gölgeye ve perspektife yer vermesiyle daha çok dikkat çeker. Onun imzasını taşıyan en az yirmi dört eser arasında 1669 tarihli Firdevsi'nin Şehname'sindeki resimler önemli bir yer tutar. Bunlarda Avrupai arka plan manzarası ve yine klasik İran resmine özgü olmayan ağaç gölgeleri açıkça görülebilmektedir. Nizami'nin Hamse eserinin 16. yüzyıla ait ünlü bir yazma kopyasında da Sultan Muhammed Nizamettin, Mirza Ali gibi 16. yüzyılın ünlü ressamları yanında Muhammed Zaman'ın imzası da bulunmaktadır. Muhammed Zaman, yazmada minyatür için boş bırakılan üç sayfayı doldurmuştur. ${ }^{12}$ Sayfa Ya Sahib-Zaman ${ }^{13}$ (Rab'i Zaman) şeklinde imzalanmıştır. Zaman, genellikle İncil ile ilgili konulardan ilham alıp Rıza Abbasi tarzında çalışmamıştır; muhtemelen Safevilerin son yıllarında oluşan ressamlar grubunun en önemlisi olarak son derece eklektik bir tarz uygulamıştır. Örneğin Resim 3'te Holofernes başkanı ile Judith Guido betimlemesi görülmektedir. 1678 ve 1689 arasında onun altı kompozisyona sahip olduğu bilinmektedir.

12 Wikipedia, "Muhammed Zaman".

13 12. Şii İmama dua bir şifre olarak kullanılmıştır. 
Resim 3: Muhammed Zaman (attrib-), Holofernes başkanı ile Judith. İran (İsfahan), c. 1680, Albüm yaprağı. Kağıt üzerinde Opak suluboya ve altın. 33.5x21 cm (sayfa). Inv Khalili Koleksiyon. No. MSS 1005. M.B. Piotrovsky and J.M. Rogers,

Heaven on Earth- Art from İslamic Lands, (Prestel Publisher, 2004), 136.

Resim 4: Açık havada şölende Bakıcılar Muhammed Zaman'a veya atölyesinde Atfedilen Muhtemelen İsfahan, yaklaşık 1650-1722 Sıva üzerine yağlı boya; 98,4 x 78,4 cm Sanat ve Tarihi Güven, Nezaket Arthur M. Sackler GALERİ, Smithsonian Enstitüsü, LTS 1995.2.121 Leyla Diba and S, Maryam Ekhtiar, Royal Persian Painting: The Qajar Epoch 1785-1925, (I. B. Tauris Publisher in association with Brooklyn Museum of Art, 1999), 128.

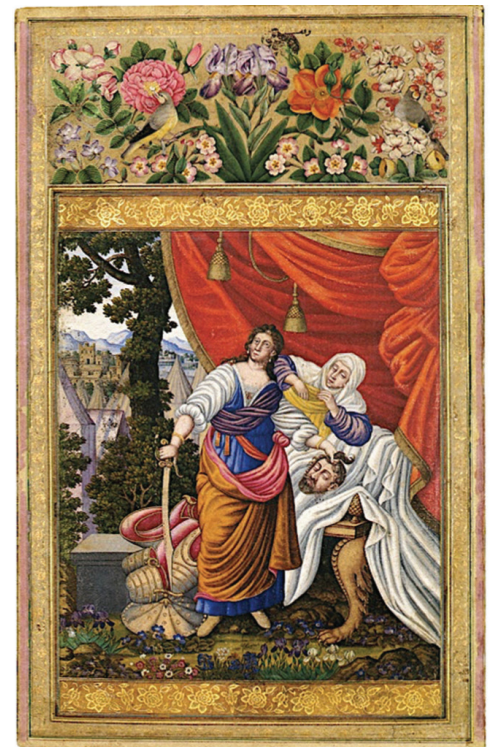

Resim 3

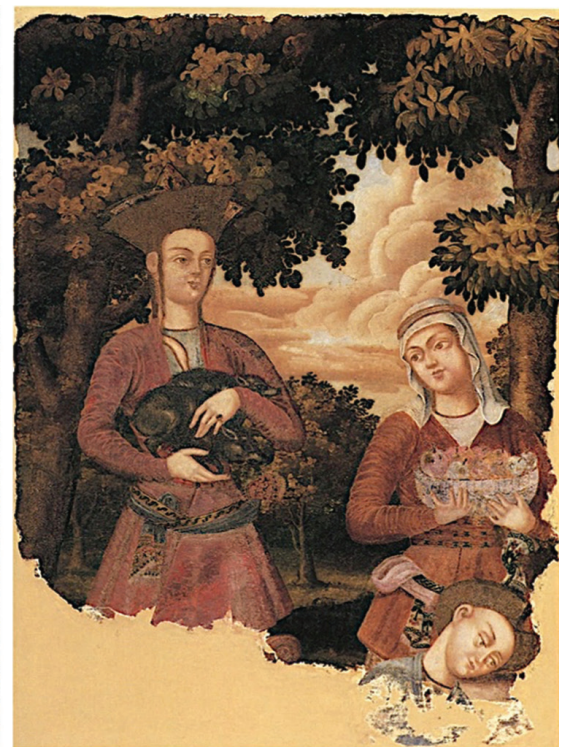

Resim 4

Caravaggio'nun bu vahşi görünümlü resminin tersine Zaman burada ön planda Judith'in elinde Holofernes'in kafasını betimlemiştir. Grubun arkasında biraz ötede ise bir şehir manzarası ve dağlar vardır. Holofernes neredeyse tamamen hacimli ve parlak kırmızı bir perde ile gizlenmiştir. Nitekim eser basit bir kafa kesme sahnesinin ötesinde karakterlerin yerine Peyzaj ve sahneye önem vererek tasarlanmıştır. Zemin, belki aykırı bir şekilde çiçeklerle menekşe, süsen ve çuha çiçeği ile kaplanmaktadır. ${ }^{14}$ Res. 4'te Zaman'ın başka bir resmi, İsfahan dışında Safevi fresklerinin bilinen

14 M.B. Piotrovsky and J.M. Rogers, Heaven on Earth- Art from İslamic Lands, (Prestel Publisher, 2004), 136. 
tek otantik örneğidir. İki görevli (kadın ve erkek), erkeğin elinde yaban domuzu vardır. Ermeni tarzı dar elbise giyen kadının elinde ise bir kase meyve gösterilmiştir. ${ }^{15}$

\subsubsection{Ali Kulu Cabbadar}

Ali Kulu Cabbadar, Şirazlı şair Lütfali Bey Adhar'ın “Ateşgede" adlı tezkiresine göre İsfahan'da Hrıstiyan mahallesinde doğmuş olmasına ve ihtida etmesine rağmen "Ali Firengi" adıyla anılmaktaydı. Yine aynı tezkire'ye göre o, II. Tahmasp ve Nadir Şah dönemlerinde "nakkaş başı” olarak görev yapmış olup 1750 yllında Mazenderan'da ölmüştür. İran resmine Avrupa resim okulunun estetiğini, tarzını ve konularını getirmiştir. Muhammed Zaman'la beraber, 17. yüzyıl sonu ve 18. yüzyıl başlarında Safevi resminde görülen Avrupa tarzının en önemli temsilcisidir. İmzasına 1660'larla 1717 arasında rastladığımız Ali Kulu Cabbadar'ın. Işslediği konular çok çeşitli olup bunlar arsinda en meşhurları Süleyman Şah, Uyuyan Nemf (1673, özel koleksiyon) ve Rus Sefirin Portresidir (1717). ${ }^{16}$

15 Leyla Diba ve S, Maryam Ekhtiar, Royal Persian Painting: The Qajar Epoch 17851925, (I. B. Tauris Publisher in association with Brooklyn Museum of Art, 1999), 129.

16 “Alikulu Cabbadar", Wikipedia, Erişim Tarihi: Temmuz 02, 2014, http://tr.wikipedia. org/wiki/Alikulu-Cabbadar/. 
Resim 5: Armor / Louis XIV Tahmini Portaiit Tarafindan Signid 'Ali Kulu Cabbadar. İsfahan, yaklaşık 1660-1690 resim: Kağıt üzerine Opak suluboya ve altın. 12.2 x 7.1 cm MUSİEE. NATIONAL DES ARTS ASIATIQUES-GUIMET. PARİS, MA2478,

Diba and Ekhtiyar, Royal Persian Painting: The Qajar Epoch 1785-1925, 111.

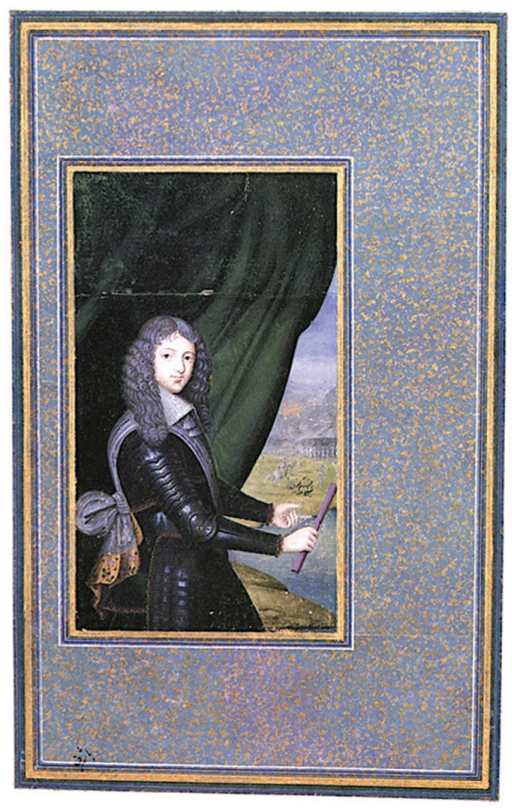

Suluboya ve lâke boya'nin yetenekli ustası Ali Kulu; Şah Abbas, Şah Süleyman ve Sultan Hüseyin (1642 - 1716) döneminde İsfahan'da aktif olan Avrupa konularını oldukça yetenekli bir şekilde yorumlayanlardandır. Resim 5'te koyu yeşil bir perdenin karşısında gölgelenmiş ve elinde cetvel tutan ayı zamanda görkemli bir zırh giyen Avrupalı genç bir prens resmin ön kısmını kaplamıştır. Prens bir elinde mareşalin otlağı ve sopasını taşır. Diğer eliyle ise izleyicileri uzak bir manzarada gerçekleştirilen orduyu keşfetmeye çağırmaktadır. Bir gölün arkasında sıralanan birlikler minik ölçek ve grisaille tekniği ile işlenmiştir. Arka plandaki şekillerin duruşu ise Ali Kulu'nun Avrupa resim yapma tekniğinin anlayışını kanıtlamaktadır.

Safevi döneminin sonlarında varlıklı ünlüler çağdaş resim albümü almaktan zevk alıyorlard1. 1664 y1lında Fransız kuyumcu Jean-Baptiste Tavernier, Avrupalı fahişelerin albümünün Şah Abbas tarafından incelemesini tarif etmektedir. Böylece ilk kez olarak Şah tek bir kadın resmi istemiş ve bunu 
Ali Kulu Cabbadar'a 1smarlamıştır (Resim 6). Bu çalışma 19. yüzyı1 oryantalist ressamlarından biri olan Jean-Leon Gerome (1824 Nisan - Eylül, 1904) resimlerinin habercisi olarak bilinmektedir.

Resim 6: Bir Kadın bir Çeşme yanında, Ali Kulu Cabbadar tarafından imzalanmıştır İsfahan, yaklaşık 1650-1660 Kağıt üzerinde Opak suluboya; / görüntü 32 x 20,5 cm, yaprak 54,6 x 44-4 cm. SANAT VE TARİHI GÜVEN, NEZAKET Arthur M. Sackler GALERİ, Smithsonian Enstitüsü, LTS 1995-2,118, Diba and Ekhtiyar, Royal Persian Painting: The Qajar Epoch 1785-1925, 115.

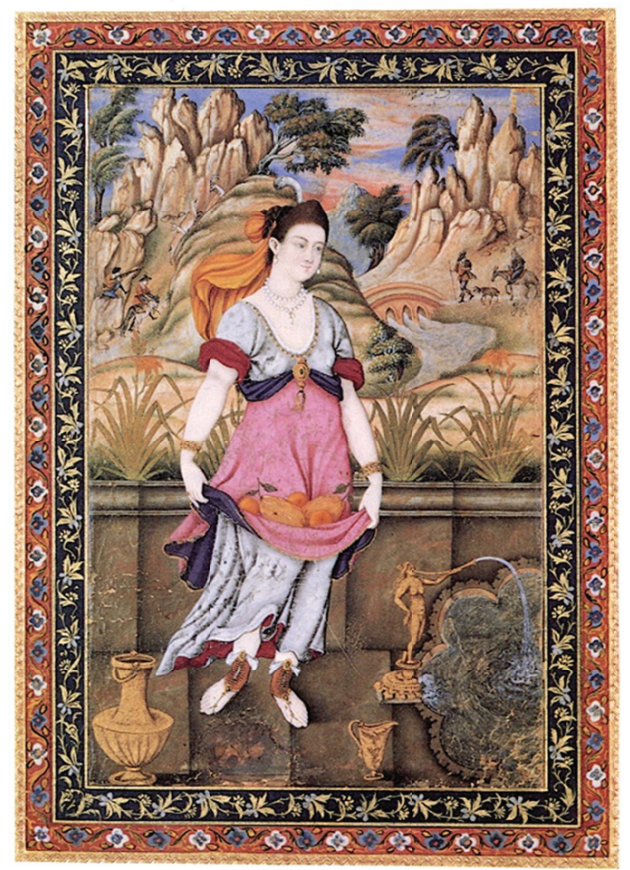


Resim 7: Şah ve O’nun saraylıları Ali kulu Cabbadar Resim ve Hat bir albümü Folio 98a İsfahan, yaklaşık 1660'larda ya 1670'larda Kağıt üzerinde Opak suluboya, altın ve gümüş; 28,2 x 42,1 cm. Şarkiyat ENSTITÜSÜ SAINT PETERS-

BURG ŞUBESİ, Rusya Bilimler Akademisi, D I4, Diba and Ekhtiyar, Royal

Persian Painting: The Qajar Epoch 1785-1925, 120.

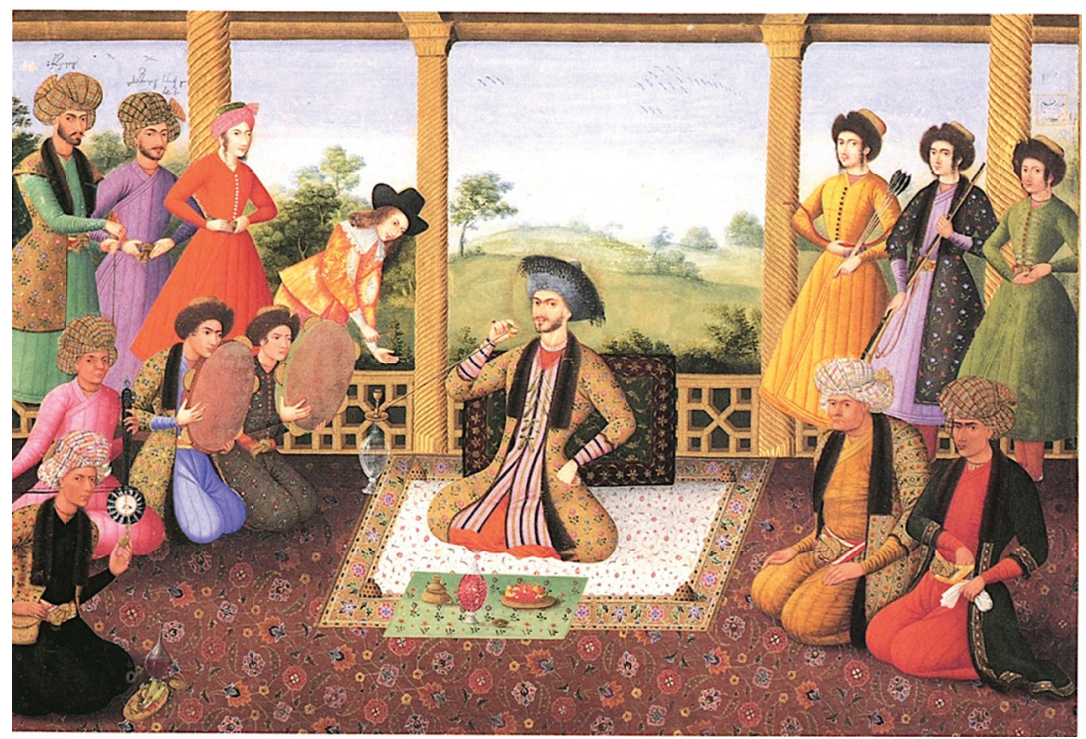

Ali Kulu Cabbadar başka bir resminde (Resim 7) genç Safevî Şah’ını (muhtemelen Süleyman) terasta otururken en sevdiği saray müzisyenleriyle göstermektedir. (1666-1694). Karmaşık törenin kompozisyonu belli bir kısıtlama ve gerginliği aktarmaktadır. Sanatçının tarzındaki belirgin özellikler şöyle ayırt edilebilir: doğal olmayan dar beller ve uzun yüzleri ile genç erkeklerin ince figürleri; minik gerçekçi detaylar; bireysel özellikleri özellikle de yaşlı adamlar (mümkünse haremağaları); massif sivrilen bez başlık (kulah); renkli yapraklarıyla bitkinin işlenişi; arka planda bulutlu gökyüzü ve puslu tepeler. Bu minyatür ressamının bazen 17. yüzyıl Babür okulu sanatçılarının minyatürlerini kopyaladığ 1 bilinmektedir. ${ }^{17}$

17 Abolala, Soudavar, Art of the Persian Courts: Selections from the Art and History Trust Collection, (Rizzoli Publisher, 1992), 25. 


\subsubsection{Bilinmeyen Resamlar}

Resim 8: Saray Elbisesinde Kafkas bir Genç, Bilinmeyen Bir Sanatçı, İsfahan, 1650-1722 Tuval üzerine yağlıboya, 155 x 80 cm. F. Farmanfarmaian'ın Koleksiyonu,

Diba and Ekhtiyar, Royal Persian Painting: The Qajar Epoch 1785-1925, 131.

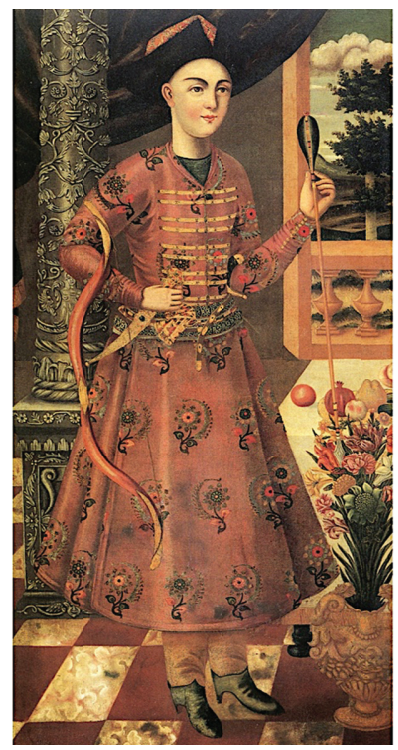

Yüksek oranda bitmiş olan ve mukemmel bir genci tasvir eden Resim 8, Safevi resminin eklektik karakteristik boyutunun örneğidir. İçteki kiremitli zemin ve vazodaki çiçekler 16. ve 17. yüzyıl Hollandalı resim ve gravürlerinden türetilmiştir. Barok tarzı bükümlü sütunu İtalyan kökenlidir; parmaklık ise İran'da bilinmeyen bir semboldür. Stilistik benzerlikler 17. yüzyıl İngiliz sarayındaki resimleri de işaretlemektedir. Zengin baronların kasvetli paleti, koyu yeşiller, canlandırmada kullanılan griler, Perso-Avrupa modu özelliğidir. Bu da Rıza Abbasi takipçileri tarafindan kullanılan palet ile tezat teşkil etmektedir. Burada modelleme ve yüz özellikleri, yuvarlak gözler, göz kapakları, burun, hilal kaşlar, Rıza Abbasi tarzına benzememektedir. Gencin dekoratif duruşu, gölge eksikliği, iki-boyutlu bir alan görüntü oluşumu, İran resminin belirgin düzen kurallarını izlemektedir. ${ }^{18}$

18 Diba ve Ekhtiar, Royal Persian Painting: The Qajar Epoch 1785-1925, 129. 
Resim 9: Bir bayan gül ile, Bilinmeyen Bir Sanatçı, İsfahan, 1704-1722 Tuval üzerine yağlıboya; I65-I x 88,8 cm. MRS Eskandar Aryeh Koleksiyonu, Diba and Ekhtiyar, Royal Persian Painting: The Qajar Epoch 1785-1925, 132.

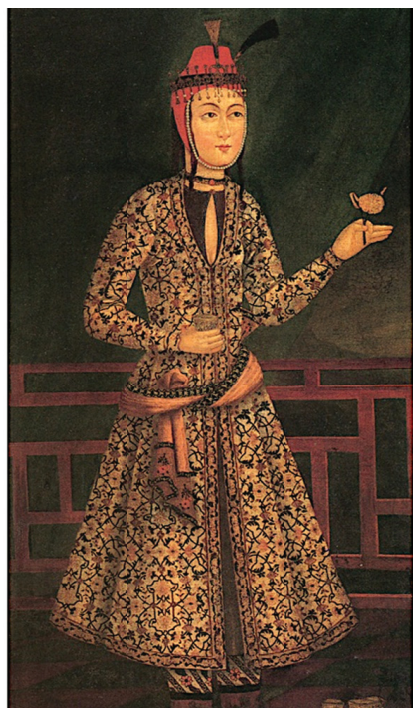

Resim 9'da zengin bir Kafkas gibi giyinen genç bir kadın betimlenmiştir. Bir elinde narin pembe bir gül ve diğer elinde bir goblet tutmuştur. Onun çekici kadınsılığı ima edilmekle birlikte sarhoş edici güzelliği de nitelenmiştir. Kadın sivri kızıl kap (çenesinin altında bağlanmış), bir tüy ve boyun kürkü ile süslenmiştir. Bu onun yüksek toplumsal statüsünü ve evli durumunu göstermektedir. Boynundaki ipek brokar desenli elbise müsrifliğini, pantolon ise ilginç bir şekilde giyindiğini iletmektedir. ${ }^{19}$ Resmin konusu tevazu ve haysiyet duygusunu yansıtmıştır.

\section{3. Çihil Sütun Sarayının Duvar Resimleri}

\section{1. Çihil Sütun Sarayının Tarihi}

İran'ın son kudretli hükümdarı olan Şah Abbas başta İsfahan olmak üzere bütün ülkede muazzam bir imar, kültür ve sanat faaliyetine girişmiştir. $\mathrm{Bu}$

19 Massumeh, Farhad, Searching for the New" Later safavid Painting and the Suz u Gawdaz (Burning and Melting) by Nau'i Khabushani. Freer Gallery of Art, Arthur M. Sackler Gallery, (Smithsonian İnstitution, Washington, D. C, 2000), 57. 
sebeple onun Safevi kültür tarihinde müstesna bir yeri vardır. Tebriz'den İsfahan'a ve oradan Hürmüz'e uzanan işlek ticaret yolunda birçok kervansaray yaptırmak suretiyle hem yol emniyetini, hem de ticaretin gelişmesini sağladı. Aynı şekilde Mazenderan eyaletini bir baştan öbür başa kateden büyük şose yol [Seng Ferş], üzerinde 1 ssız ve tehlikeli yerlerde yapılan kervansaraylar da onun eseridir. Tabii ki bu faaliyetler arasında İsfahan şehri her zaman en gözde yer olmuştur. Şah Abbas başkenti olan İsfahan şehrini güzelleştirmek ve büyütmek gereği duymuş; meydanlar, köprüler, saraylar, yollar vs. yapmıştır. Bunlardan bazılarının çok meşhur olduğunu söyleyebiliriz. Şah Abbas'ın inşa ettirdiği meydan-1 nakş-1 Cihan'da bulunan yapıtlar dünyada şöhretli olup UNESCO tarafindan koruma altındadır. Bunlar, Mescid-i Şah, Mescid-i Şeyh Lutfullah, Serder-i Bazar-Kayseriye ve Âli Kapu'nun Çihil Sütun'undan (Res.10-11) ibarettir.

Resim 10: Çihil Sütun sarayı, Fourty Columns, "Chehel Sutun", Flicker Photos, Google, Erişim tarihi August 26, 2016, (http://www.flickr.com/photos/youngrobv/1803476053/).

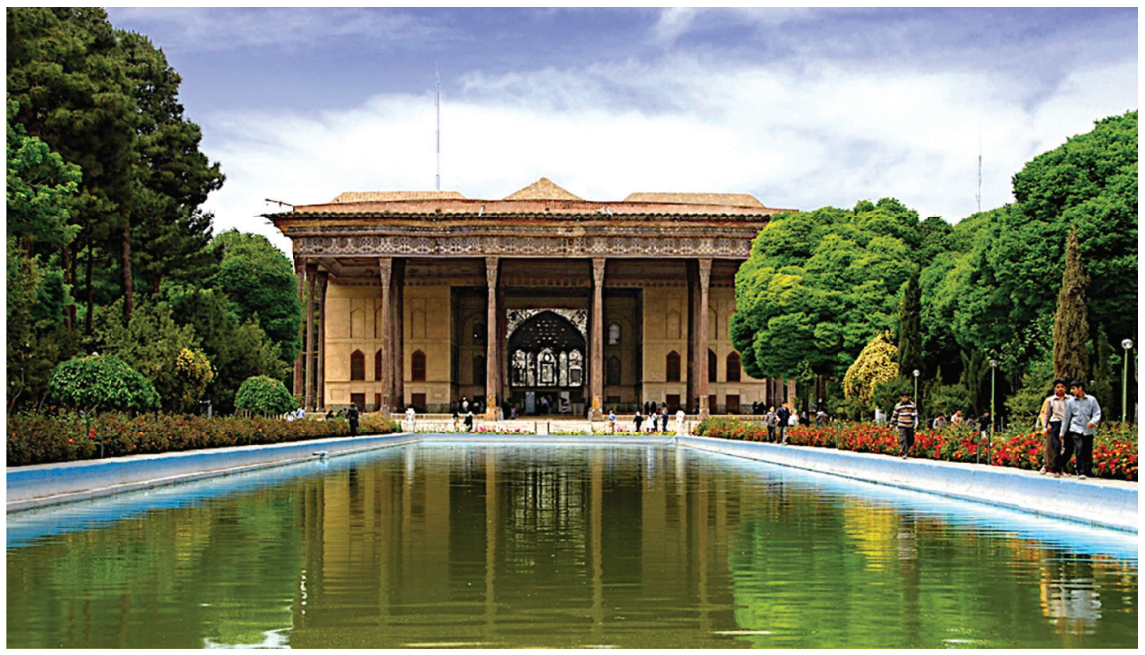


Resim 11: Çihil Sütun saray1, "Fourty Columns, Chehel Sutun”, Flicker Photos, Google, Erişim tarihi Mayıs 14, 2017, (http://www.flickr.com/photos/youngrobv/1803476053/).

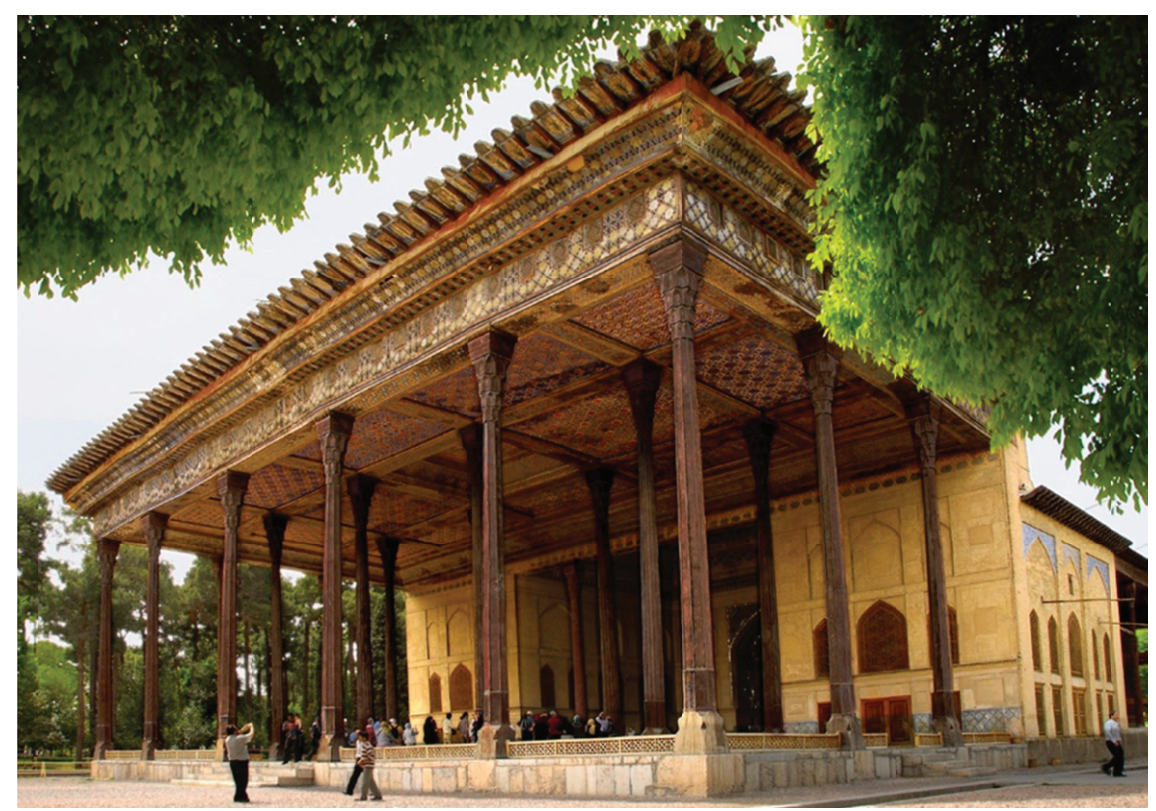

Çihil veya Çihil Sütun Farsça da "Kırk Sütun” anlamına gelir. Halk arasında yayılmış bir söylentiye göre eyvanın yirmi sütununun sayısının, bahçedeki havuzun suyunda yansımasıyla kırka çıkması, sarayın adının kaynağını oluşturur. ${ }^{20}$ Ebba Koch, Çihil Sütun isimli saraylarla ilgili makalesinde Safevi, Babürlü ve Timurlu sivil mimari kültüründe kabul salonlarının genellikle Çihil Sütun olarak anıldığını belirtir. ${ }^{21}$ Koch makalesinde aynı tarihlerde Babürlerin beşinci hükümdarı Şah Cihan’1n (1627-1658) Delhi'de yaptırdığı Çihil Sütun Sarayı'nı ve bundan önce Şah Tahmasb’ın Kazvin'deki Çihil Sütunu'nu örnek verir. Yazar, bu çok sütunlu sarayları Fars kültürünün bir uzantısı olarak yorumlayarak Persepolis’te örnekleri görülen Ahameniş çok sütunlu saray mimarisinin Sasanilerle devam edip

20 N. M. Rostami, Memari-i İsfahan, (Tahran: Vajehara, 2011), 115.

${ }^{21}$ E. Koch, Diwan-i 'Amm and Chihil Sutun the Audience Halls of Shah Jahan, In Muqarnas XI an Annual on Islamic Art and Architecture, Gülru Necipoglu (Ed.)( Leiden E.J. Brill, 1994), 143. 
İslam'dan sonra İran'da Arap olmayan hanedanların saray mimarisinde de kullanıldığını belirtir.

Safevi edebiyatında Persepolis'teki antik dönem yapılarına değişik isimler verilir, bunlardan biri Çihil Sütun'dur. Çihil Sütun (Kırk Sütun), Çihil Minar (Kırk Minare) ve Sed Sütun (Yüz Sütun) Perspolis'in kalıntılarına verilen isimlerdendir. ${ }^{22}$ Koch'a göre bu tip sarayların çok sayıda yapılması bugünkü İran topraklarına sonradan hakim olan diğer milletlerin, Pers kültürüne karşı duyulan hayranlık ve benimsemeleriyle bağlantılıdır. ${ }^{23}$ Kuşkusuz bu benzetme ve adlandırma yapıların doğrudan sütun sayısı ile ilgili olmaktan ziyade sütun sayısının çokluğuyla bağlantılıdır. Nitekim ne Persepolis, ne Kazvin ne de İsfahan'daki Çihil Sütun saraylarının kırk sütunu yoktur.

Bazı tarihçiler II. Şah Abbas'ın (1632-1666) yaptırdığı binanın kırk sütununun olduğunu ve bir yangında eyvanın bir kısmı harap olduğunu ve sadece yirmi sütunun yangından kurtulduğunu öne sürerler. ${ }^{24}$ Restorasyon ustas1 Lotfollah Honarfar ise İsfahan mimarisi hakkındaki kitabında bu teorinin yanlış olduğunu vurgular ve restorasyon sırasında rastlanan yangın izlerine dayanarak böyle bir şeyin olmadığını ispatlar. ${ }^{25}$ Honarfar'a göre Sultan Hüseyin dönemindeki düzeltmelerde saray eski haline dönüştürülür. Ayrıca Chardin 1666'da bu sarayı anlattığında büyük eyvandaki on sekiz altın yaldızlı ve aynalı sütundan bahseder. ${ }^{26}$ Bu deliller binanın Şah Abbas döneminden bugünkü durumuna getirildiğini gösterir.

Şah Abbas döneminden Sultan Hüseyin dönemine kadar saray tarihçisi olan Mirza Muhammed Vahid Kazvini'nin (öl.1710) yazdığı Abbasname'de ${ }^{27}$ 1118/1706 yılında köşkte çıkan bir yangından söz edilir. Kazvini’ye göre Sultan Hüseyin dönemindeki bu yangında hasar gören bölümler aynı yıl-

22 Chardin kitabında bu kalıntılardan Çihil Minar olarak söz eder( J. Chardin, A Journey to Persia, R.W. Ferrier (Ed.), (London NewYork: I.B. Tauris Publication, 1996), 156).

23 Koch, Diwan-i 'Amm and Chihil Sutun the Audience Halls of Shah Jahan, In Muqarnas XI an Annual on Islamic Art and Architecture, 143.

24 Rostami, Memari-i İsfahan, 118.

25 L.Honarfar, Ganjine-i Asar-i Tarikhi-i İsfahan, (Tahran: Chap-e Ziba, 1971), 125.

26 Chardin, A Journey to Persia, 146.

27 M. Ferrante, Travaux de restauration de monuments historiques en İran, Zander G. (Ed.), (Rome: IsMEO, 1968), 293. 
larda düzeltilerek saray önceki haline dönüştürülür. ${ }^{28}$ Nitekim yukarıda söz edilen giriş eyvanındaki kitabede 1118 H./1706 M. yılındaki bu tamirattan bahsedilir.

Şah Abbas İslamiyet öncesi İran uygarlıkları özellikle Ahamenişleri (M.Ö.550-330) izleyerek başta Nevruz bayramı olmak üzere yılın büyük olaylarını ve törenlerini bu sarayda yaptırır. Ahamenişler döneminde çok sütunlu sarayların önünde yapılan bu kutlamalar Şah I. Abbas ve ardılı Safevi hükümdarlarının zamanında Çihil Sütun sarayının bahçesinde yap1lir. ${ }^{29}$

Safevi döneminde I. Şah Abbas'in emri üzere İsfahan'da uzun bir cadde yapılmıştır. Bu caddenin ismi Çehar Bağ'dır. Bu caddenin her iki yanında da bağlar yapılmıştır. Bu bağların sonu Meydan-1 Nakş-1 Cihan'da biter. Yapılan şehircilik planında bu görüntü son derece güzel bir görüntüye sahiptir. Çihil Sütun bu cadde ve meydanların ana merkezi halinde inşa edilmiştir.

Res. 12 de Çihil Sütunun emaretinde görülen Talar (salon) ve etrafindaki odalardır. Şah Abbas kendi padişahlık döneminde bu salonu yabancı misafirleri ağırlamak için kullanmıştır. Bu salonu ziyafet salonu olarak kullandığından dolayı daha gösterişli ve güzelliği ile dikkati çekecek şekilde yaptırmıştır. ${ }^{30}$

28 Mirza Muhammed T. V. Kazvini, Abbas Name, Sait M. Sadegh (Ed.), (Tahran: Pajuheşgah-i Olum-i İnsani, 2003), 91.

29 A. Aghajani ve H. Javani, Divar negari-i asr-i safevi - Kakh-i Chehel Sutun, (Tahran: Ferhengistan-i Honar, 2007), 10; Sussan Babaie, "Shah Abbas II, the conquest of Qandahar, the Chihil Sutun, and its wall painting”, February 1994, No.126, http:// archnet.org/library/documents/one-document.jsp?document_id=3695); Koch, Diwan-i 'Amm and Chihil Sutun the Audience Halls of Shah Jahan, In Muqarnas XI an Annual on Islamic Art and Architecture, 147-149.

30 Babaie, Shah Abbas II, the conquest of Qandahar, the Chihil Sutun, and its wall painting, 126. 
Resim 12: Çihil Sütunun planı. kırmızı çizgi: sarayın temeli I. Şah Abbas, Mavi çizgi: II. Şah Abbas, Sarı çizgi: Şah Sultan Hüseyin dönemine aittir, A. Aghajani ve H. Javani, Divar negari-i asr-i safevi - Kakh-i Chehel Sutun, (Tahran:

Ferhengistan-i Honar, 2007), 115.

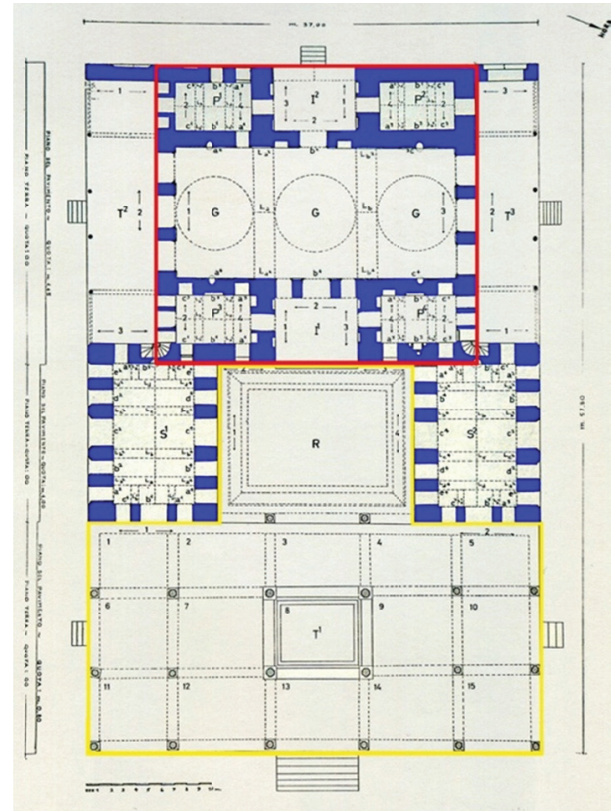

Caberi Ansari'ye göre, Safevi dönemine ait İsfahan'da bulunan imarat ve binalar I. Şah Abbas’ın döneminde geliştirilip güzelleştirilmiştilerdir. Bu eserleri II. Şah Abbas Osmanlı İmparatorluğu ile sulh yaptığı zaman 1647 (1026 h.ş) yaptırmış ve ilavelerde bulunmuştur ki bu yıllar Şah Abbas'ın beşinci Saltanat yılına denk gelmektedir. Yalnız dişardaki eyvanda duvardaki kitabede nestaliğ yazısı ile 21 Ramazan 1706 (1085 h.ş) de yangın çıktı̆̆1 yazar. ${ }^{31}$

Kerim Pirniya’nın, “Sebk Şenasi Memari Iran” (İran mimarisinin üslubunun tanımı) adlı eserinde Çihil Sütun hakkında şöyle der: "Çihil Sütun, şimdiye kadar Safevi Devletin'den kalan en görkemli eyvanlardan birisidir." Aynı eserde ayna işçiliği, binanın güzelliği, süslemelerin çok güzel olduğu, renkli camları, münebbetkari (ahşap işlemesi) hatemkari, desenler ve resimlerin güzelliği’” ... uzun uzun anlatılır. Yine Kerim Pirniya, ön

31 Aghajani, Javani, Divar negari-i asr-i safevi - Kakh-i Chehel Sutun, 10. 
eyvanın sultan makamına ait olduğunu, yan odaların vezirlere ve büyük önemli mevki sahibi olan kişilere ait olduğunu yazar.

Artur Upham Pope göre "Çihil Sütun bağı, daha önceleri Cihan Bağı olan bir yapıdır. İçinde köşkleri ve emareti olan bir külliyedir. I Şah Abbas tarafından 1600 (979 h.ş) da yaptırılmıştır. Bu binanın sonradan adı Çihil Sütun olup halen İsfahan'da bulunmaktadır" diye izah eder. ${ }^{32} \mathrm{Bu}$ verilen tarih, salonun duvarında alçı süslemelerin (kartonpiyer) üzerinde yazılan Şiirlerde ebced hesabı ile düşürülen tarihtir.

Caberi Anasari, binanın mimarisini kitabında şöyle izah eder:

"Çihil Sütun 20 sütundan oluşan bir binadır (Res.13). Bunun 18 sütunu eyvanı tutan kolonlardan ibarettir. İki tanesi de salonun ön klsmında yer alır. Bu eyvan binanın doğu kismında yer alır. Bu sütunların bulunduğu eyvanin boyu 38.m, eni $17 \mathrm{~m}$, yerden yükseliği ise $14 \mathrm{~m}$ dir. Bu eyvan binanın doğu kısmında yer alır. Sütunların yapıllş̧ silindirik ve çokgenden ibarettir. Dördüncü sütunun kaidesi taştandır. Bu taşların üzerinde kabartma aslanbaşı tasvirleri bulunmaktadır. Bu kısım Şahın misaferlerine ayırılan bölümdür". ${ }^{33}$

Resim 13: Çihil Sütun sarayı. sütunların görüntüsü. Tavanı geometrik ve çeşitli renkler ile süslenmiştir, "Fourty Columns, Chehel Sutun", Wikipedia, Google,

Erişim Tarihi Aralık 20 2016, (http://tr.wikipedia.org/wiki/Çihil_Sütun).

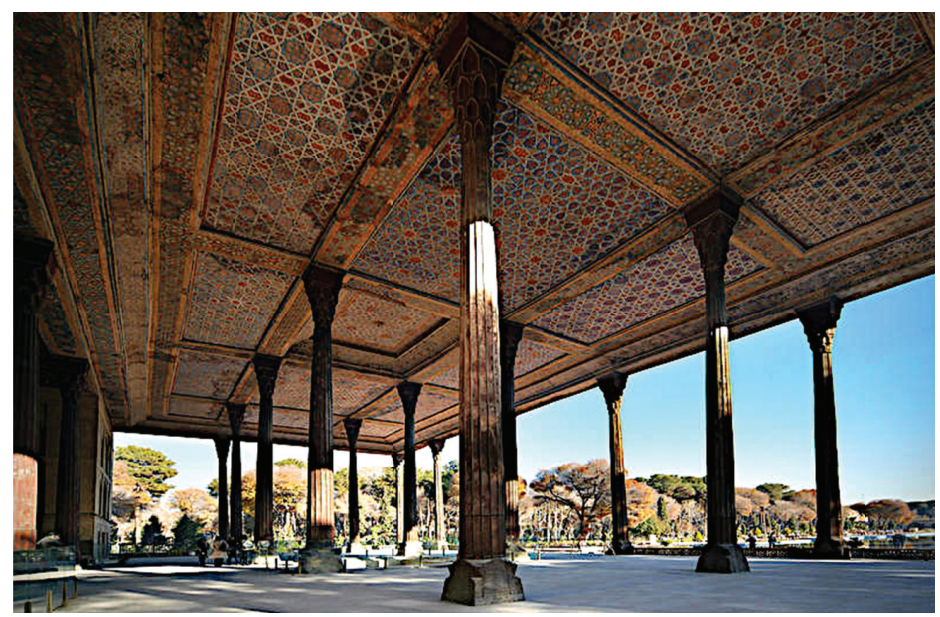

32 Arthur Opham Pope, İran'nin sanat şaheserleri, (Tehran: Elmi- Ferhengi (ilim-kültür) yayını, 2012), 67.

33 Aghajani, Javani, Divar negari-i asr-i safevi - Kakh-i Chehel Sutun, 10. 
Eyvanın etrafinda bulunan iki tane oda Şah Abbas dönemine aittir. Bu odalardaki resimler alçı üzerine yapılmış olup Rıza Abbasi'nin üslubunu taşır. Üçüncü eyvanın ölçüleri 7x5,5 metre ve Şahneşindir (Şah'ın makam yeri). Tabanı ve Orthostat (duvarlardaki taş döşeme- Farsçada izare denilen ve garnizin üzerine gelen duvar) mermer taştan döşenmiştir. Bu orthostatlar nakışlıdır. Tavan ise tamamen ayna işçiliği ile işlenmiştir. ${ }^{34}$

Eyvanın iki tarafinda dört portre resim nişlerin içine yapılmıştır. Bu resimlerden iki tanesi Avrupa üslubunda ve yağlı boya tekniği ile yapılmıştır; Diğer ikisi ise İran üslubunu taşır (Res.14-15). Ayrıca iki levhada Kuran Kerim'den ayetler yazılı olup bu yazı Şemsettin Bin Molla Muhammed Seyyid Ceylani'ye aittir. ${ }^{35}$

Resim 14: Çihil Sütun sarayı. Kuzey eyvandakı Avrupa tarzı iki portre, resim yazar tarafindan çekilmiştir.

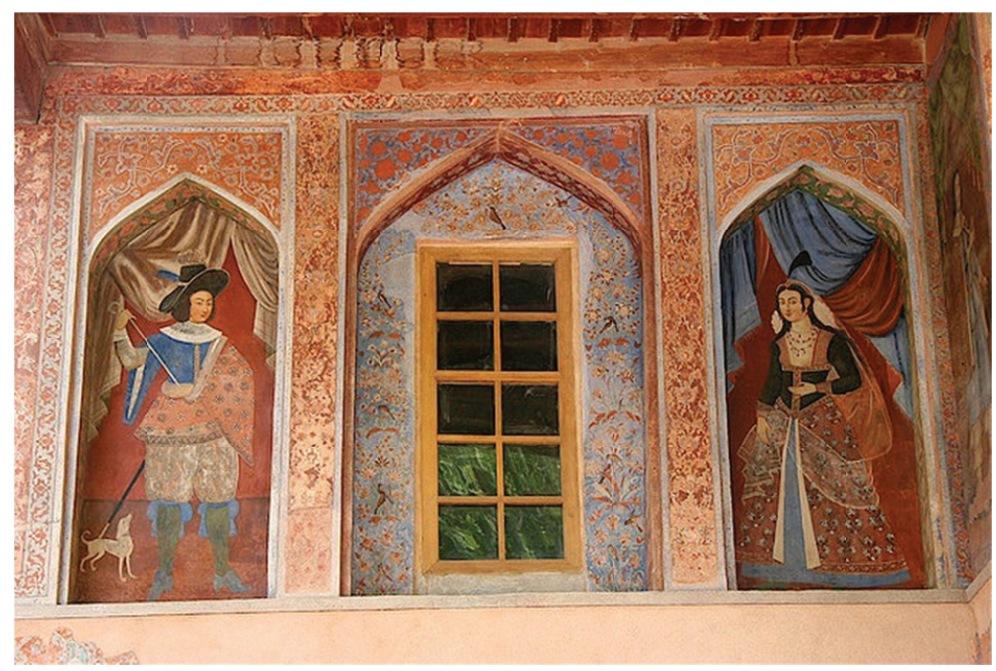

34 Aghajani, Javani, Divar negari-i asr-i safevi - Kakh-i Chehel Sutun, 11.

35 Aghajani, Javani, Divar negari-i asr-i safevi - Kakh-i Chehel Sutun, 12. 
Resim 15: Çihil Sütun sarayı. Kuzey eyvandaki Avrupa tarzı portreler, resim yazar tarafindan çekilmiştir.

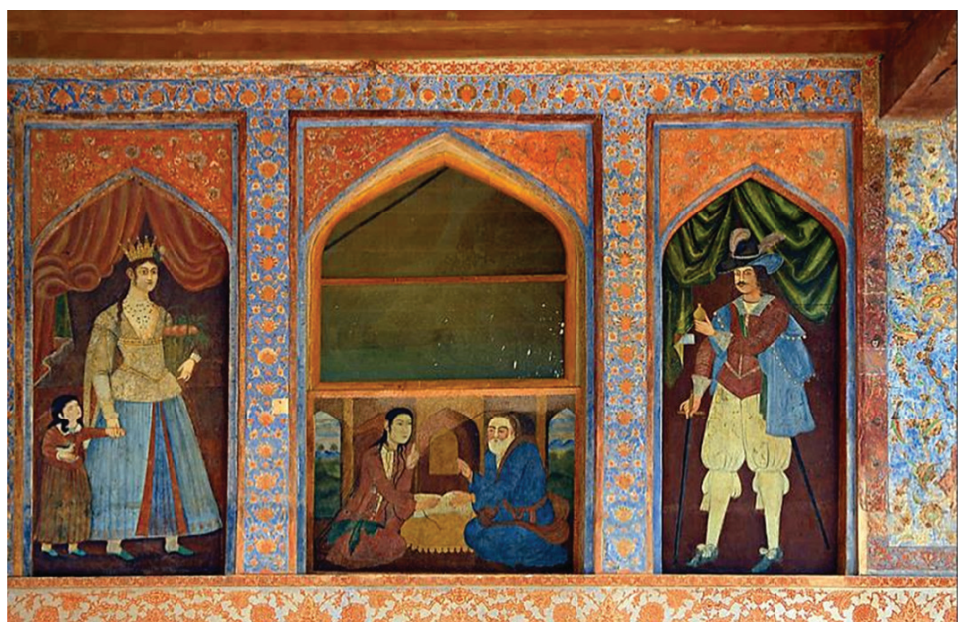

Resim 16: Çihil Sütun sarayı. Hüsrev ile Şirin 159x $177 \mathrm{~cm}$, resim yazar tarafından çekilmiştir.

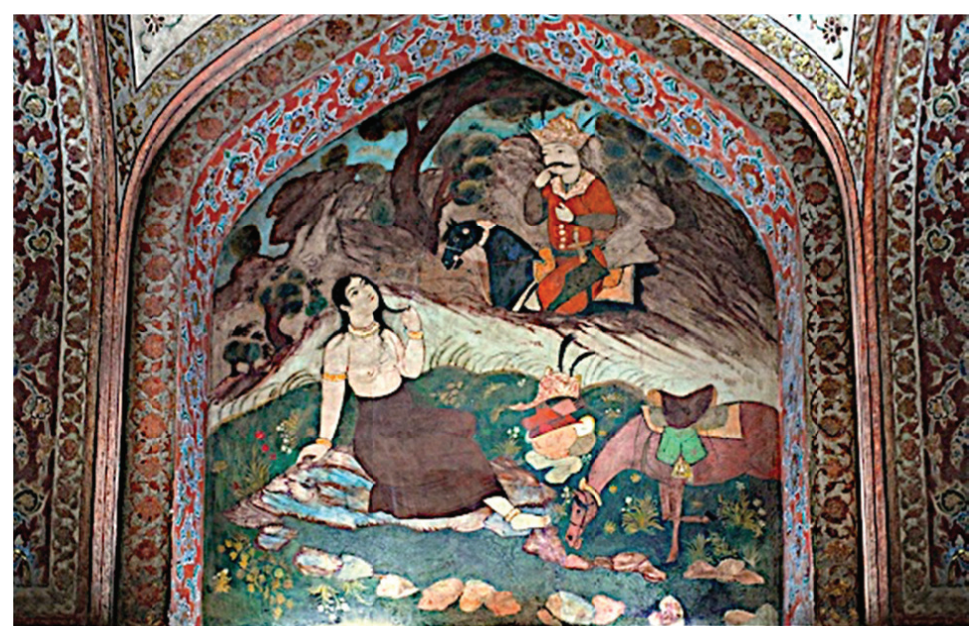

Batıda yeralan eyvanda İran üslubu ile yapılan resimler hala yerindedir. Bu eyvanın bazı resimlerinde Rıza Abbasi’nin üslubu dikkat çeker. Şahnişin'in iki tarafında yani kuzey ve güneyinde Şah Abbas'a ait iki tane oda vardır. Kuzeydeki odada on iki adet resim bulunur. Bu resimlerden bir tanesinde 
bir ziyafet ve bezm sofrasında tacı ile Şah görülmektedir. Bu resim İsfahan üslubu ile yapılmıştır. Güneydeki odada bulunan tasvirlerin çoğu İran üslubu ile yapılmıştır. Bunlardan yalnız bir tanesi Hint üslubunda yapılmış bir tasvirdir. Bir başka resimde de Yusuf ile Züleyha'nın meselesi anlatılır. Bunun karşısındaki uzun nişlerde görülen ve doğu- batı yönünde bulunan tasvirler ise Hüsrev ile Şirin'e aittir (Res.16).

$\mathrm{Bu}$ resimlerin içinde en meşhur olanı Hintli Şehzade hanımın eşinin ölümünden sonra kendisini ateşte yakarak kurban etmesini anlatır (Res.17). Bu odanın güneyindeki bu eserin dışında da Hint üslubu ile yapılan resimler vardır.

Çihil Sütun'un önemli olan salonu $22 \mathrm{~m}$ uzunlığunda $11 \mathrm{~m}$ eninde, $21 \mathrm{~m}$ yükseliğinde ve üç kümbeti olan bir salondur. Bu kümbetleri tutan tromplar görülmektedir. Trompların etrafindaki desenler dikkati çeker. Salonun etrafinda orthostat üzerinde 24 tane resim vardır. Bunların bazıları I. Şah Abbas dönemine aitir. Bu salondaki altı büyük tablo değişik tekniklerle yapılmıştır.

Resim 17: Çihil Sütun sarayı. Vişnudas eseri zanedilmektedir, Hintli Şehzade hanımın eşinin ölümünden sonra kendisini ateşte yakarak kurban etmesi, "Fourty Columns, Chehel Sutun", Flicker Photos, Erişim tarihi kasım 01, 2016, http:// www.flickr.com/photos/youngrobv/1803476053/.

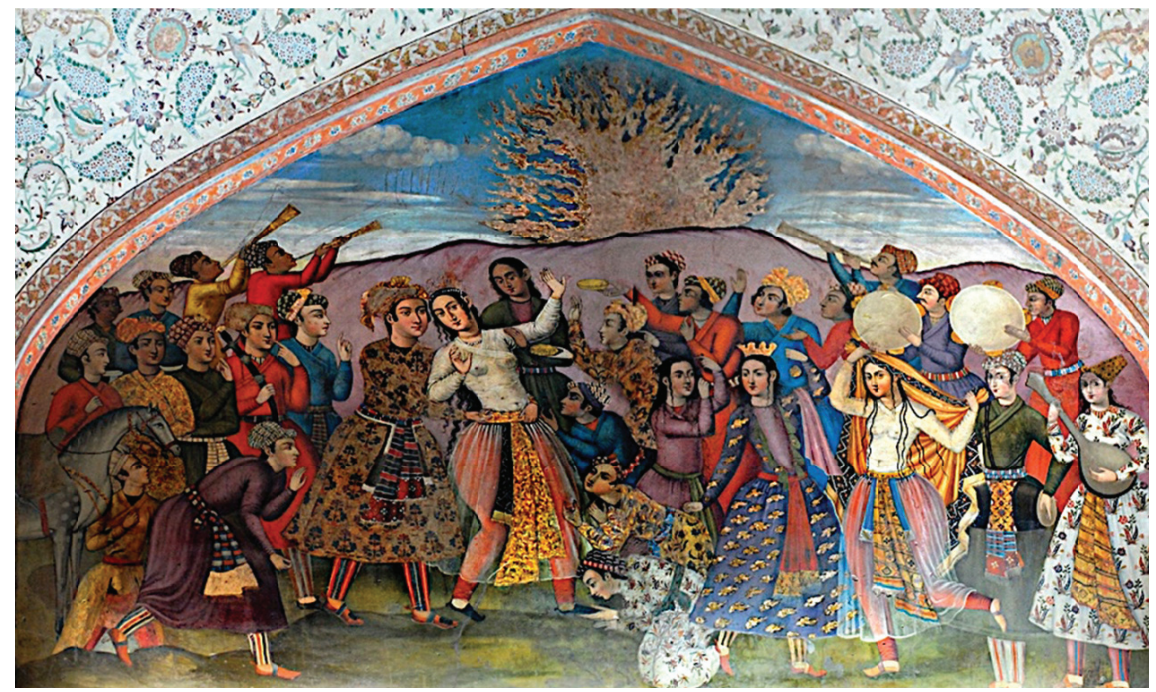


Genel olarak bu binada bulunan resimleri şu şekilde ayırabiliriz:

I. Merkez salonda bulunan tasvirler ve köşelerde bulunan tromplar, kuzey ve güneyde bulunan odadaki resimler, batı-doğudaki eyvanda bulunan resimler İran üslubu ve Rıza Abbasi'nin tekniği gösterir.

II. II. Şah Abbas döneminde, kuzey ve güneye büyük odalar ve eyvan ilave edilmiştir. Buradaki resimler de Rıza Abbasi'nin ve öğrencilerinin üslubundadır. Bu tasvirlere bakıldığı zaman I. Şah Abbas dönemine ait olan tasvirlerden kopyalanmış veya tesiri altında kalarak yapıldığı anlaşılmaktadır. Çünkü resimler Rıza Abbasi'nin orjinal çalışmasının kopyası gibi görünmektedir. Zira üstadın çizgilerinin maharetini ve zerafetini göstermektedir.

III. Avrupai tarzda yapılan resimler Çihil Sütun eyvanının kuzey ve güney yandaki nişlerinde (bu eyvan aynalı talar olarak isimlendirilmiştir) görülmektedir (Res: 6-7). Büyük bir olasılıkla sarayda ressam olarak çalışan yabancı Avrupalı kişilere aittir.

IV. Merkez olarak kullanılan salonda, bulunan büyük resimlerde görülen üslup İran/Avrupa ve Hint üslubunun karışımıdır. Bunun en güzel örneği, Hintli Şehzade Hanımı'nın kendini kurban etme sahnesini gösteren tasvirdir.

$\mathrm{Bu}$ üç üslubu ortaya çıkaranlar II. Şah Abbas zamanında çalışan İranlı ressamlardır. Bunlar İran üslubunun dışında Avrupa sanatına gösterdikleri hayranlıktan bu üslup ortaya çıkmıştır. Bunlar "Muhammed Zaman, Behram Sofrekeş ve Ali Kulu Cebbadar" dır.

V. Çaldıran Savaşı'nı anlatan tasvir Zend/Kaçar dönemine aittir (Res. 2). Tablonun alt kısmında Aka Sadik/ Sadik El-Vad 1795 (1174 h.ş) isim ve tarihine taıf yapılmıştır.

\section{2. Çihil Sütun Duvar Resimlerinin Sıralaması}

Çihil Sütunun duvar resimlerinde (R.18), üç türlü üslup vardır ve bu resimleri dört kısma ayırabiliriz. Bu üsluplar;

I. Rıza Abbasi ve öğrencilerinin üslubu, bu resimlerde beceri, renklendirme, figürler, oldukça dikkat çekmektedir ve Çihil Sütunun ana binasında (main hall) yer alır. 
II. II. Şah Abbas döneminde duvar resimlerine eklemeler yapılmış ancak bu resimler de Rıza Abbasi üslubu taklidinde ve etkisinde kalmıştır.

Resim 18: Çihil Sütun sarayının alınan resimlerin planı, S.Babaie, Shah 'Abbas II, The Conquest of Qandahar, the Chihil Sutun and Its Wall Paintings, Muqarnas XI an Annual on Islamic Art and Architecture, Gülru Necipoglu (Ed.), (Leiden:

E.J. Brill, 1994), 127.

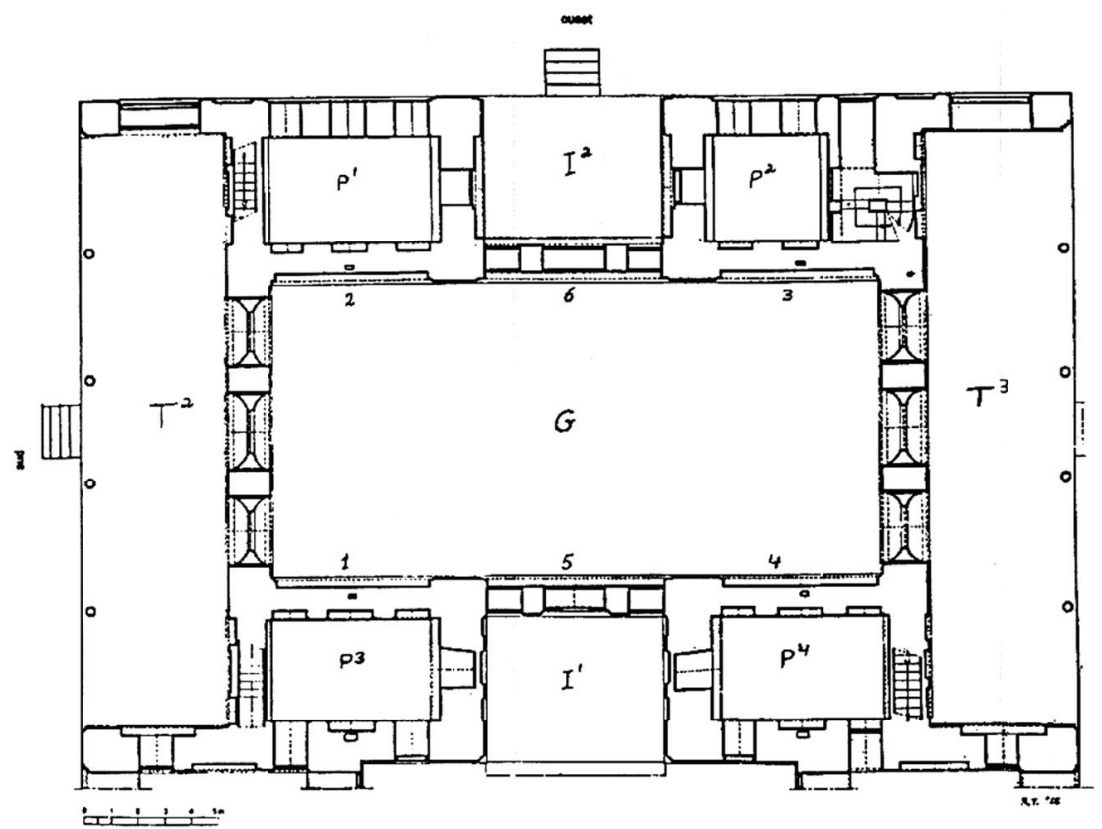

Fig. 3. The Chihil Sutun. Schematic plan of the audience hall $(G)$, the four corner rooms $\left(\mathrm{P}^{1-1}\right)$, the two iwans $\left(\mathrm{I}^{1-2}\right)$, and the two verandas $\left(\mathrm{T}^{2-s}\right)$. Placement of the large paintings in the audience hall: (1) Battle of Ismacil and the Uzbeks; (2) Shah Tahmasp and Humayun; (3) Shah "Abbas I and Vali Muhammad Khan; (4) Shah 'Abbas II and Nadr Muhammad Khan; (5) Battle of Nadir; (6) Battle of Chaldiran. (Plan: After Ferrantc, "Cihil Sutün," fig. 4, p. 801)

III. II. Şah Abbas 1642-1666 devrinde Avrupai tarzda resimler görülmeye başlamıştır. Bu resimlerde yabancı ressamlar da çalışmıştır. Bunlardan önemli olanları olarak Lokar, Angel, Hasselt, Minas, Vishnodas'1 sayabiliriz.

Bunların dışında İranlı sanatçılar tarafından yapılan resimler de vardır ve bu resimler Avrupai tarzı ile Rıza Abbasi tarzını katarak yağlı boya ile yapılmıştır. Bu resimler de büyük salonun duvarlarında görülmektedir. Bunlar; 
1. Şah Abbas ve Türkistan Şahı'na verilen ziyafeti anlatan resim, (Res.19).

2. Çaldıran Savaşı, (Res.20).

3. Şah Tahmasb'ın Hindistan Şahı Hümayun'a verdiği ziyafet ve eğlence (bezm) sahnesi, (Res.21).

Karşı tarafta yani doğudaki duvarda ise sağdan sola şu resimler bulunmaktadir:

1. Taherabad harbinde I. Şah İsmail'ın Özbek Şibek Hanı'nı yenmesi ve öldürmesi konusu işlenmiştir, (Res.22).

2. Hintlilerle Nader Şah'ın savaşı, (Res.23).

3. II. Şah Abbas'ın Türkistan Şah'ina verdiği ziyafet ve eğlence töreni, (Res.24).

Resim 19: Çihil Sütun saray. Şah Abbas ve Türkistan Şahına verilen ziyafeti anlatır, "Fourty Columns, Chehel Sutun", Flicker Photos, Google, Erişim tarihi Mart 20, 2017, http://www.flickr.com/photos/youngrobv/1803476053/.

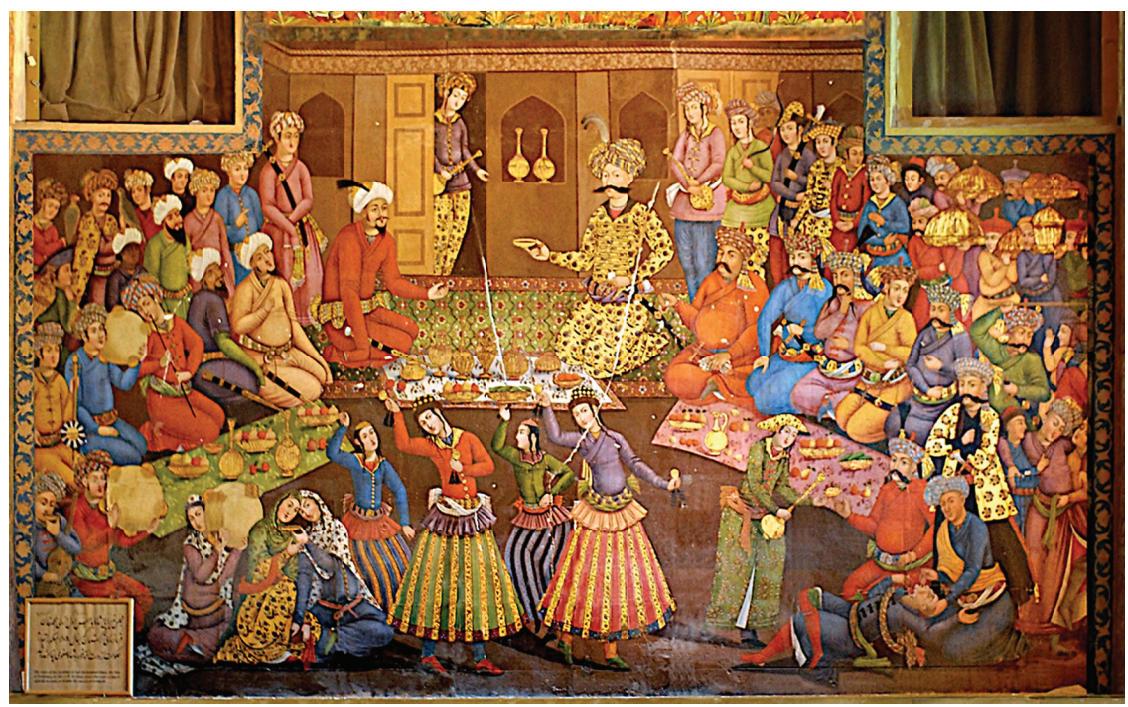


Resim 20: Çihil Sütun sarayı. Çaldıran savaşı, Sadıg- ul va-ad atıflıdır. Avşariye veya Zendiye dönemine aitdir, "Fourty Columns, Chehel Sutun”, Flicker Photos, Erişim tarihi Temmuz 09, 2015, http://www.flickr.com/photos/youngrobv/1803476053/.

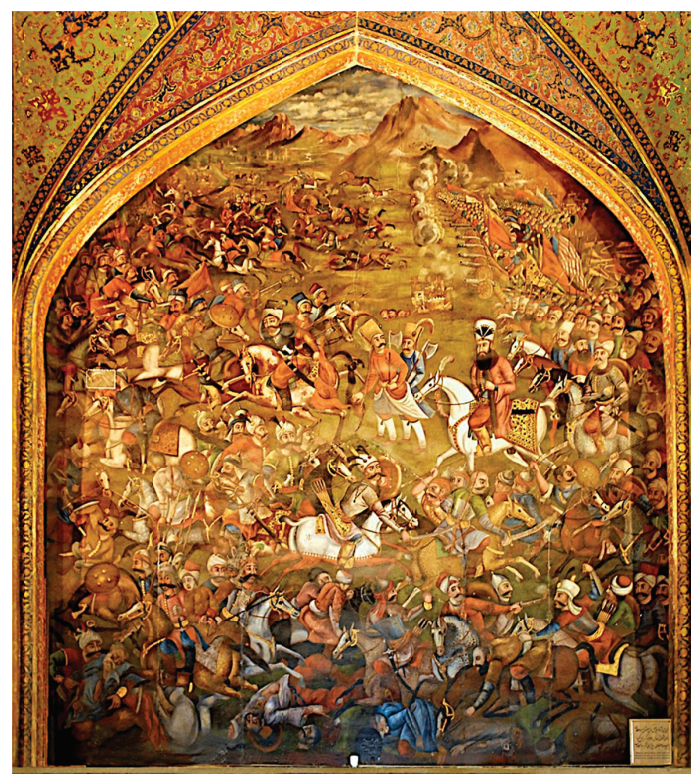

Resim 21: Çihil Sütun sarayı, Şah Tahmasb'ın Hindistan Şahı Hümayun'a verdiği ziyafet ve eğlence sahnesi, A. Aghajani ve H. Javani. Divar negari-i asr-i safevi - Kakh-i Chehel Sutun, (Tahran: Ferhengistan-i Honar, 2007), 69.

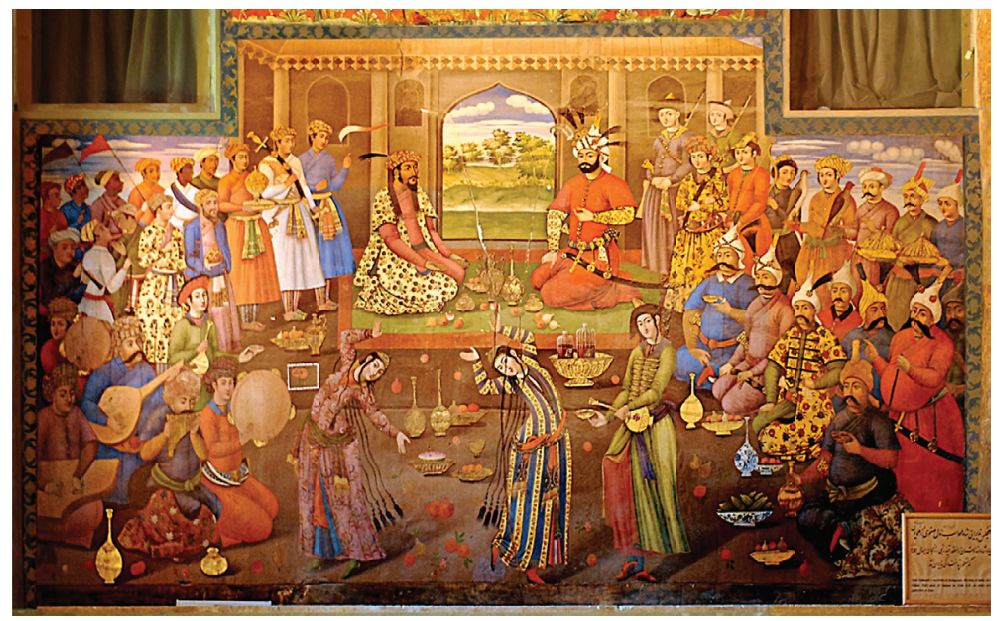


Resim 22: Çihil Sütun Sarayı, Taherabad harbinde I. Şah İsmail'ın Özbek Şibek Hanı'nı yenmesi tasvir edilmiştir, "Fourty Columns, Chehel Sutun”, Flicker Photos, Google, Erişim tarihi Ağustos 25, 2017, http://www.flickr.com/photos/ youngrobv/1803476053/.

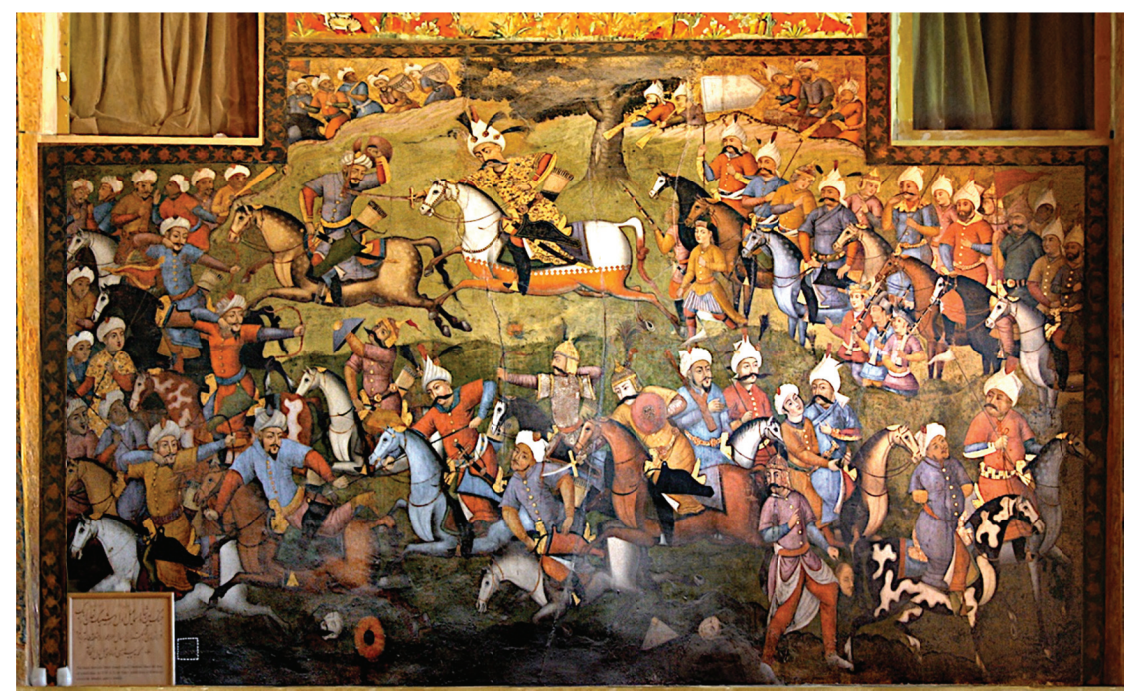

Resim 23: Çihil Sütun sarayı, Hintlilerle Nader Şahın savaşı Avşariye dönemine aittir, A. Aghajani ve H. Javani. Divar negari-i asr-i safevi - Kakh-i Chehel Sutun, (Tahran: Ferhengistan-i Honar), 2007, 74.

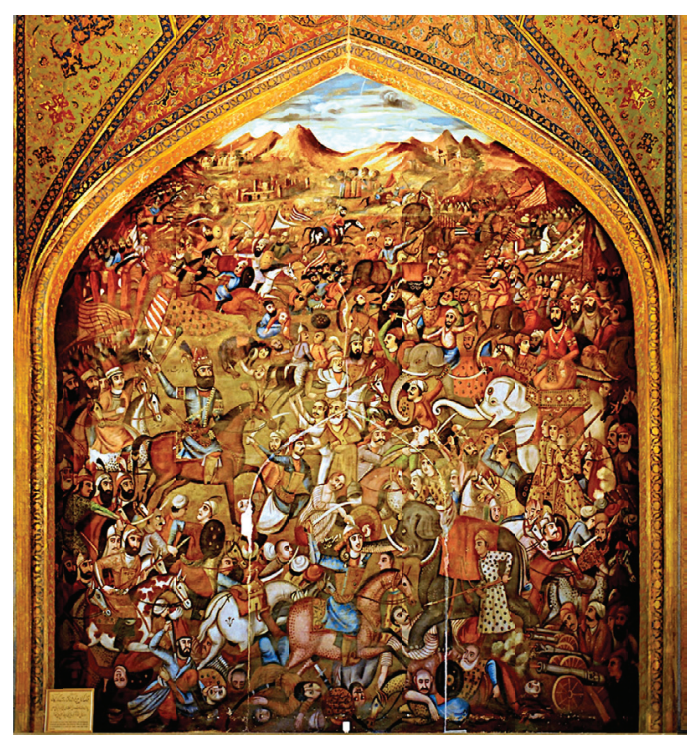


Resim 24: Çihil Sütun sarayı, II. Şah Abbas'ın Türkistan Şah'ına verdiği ziyafet ve eğlence töreni, Fourty Columns, Chehel Sutun, Flicker Photos, Google, Erişim tarihi Ekim 24, 2017, http://www.flickr.com/photos/youngrobv/1803476053/.

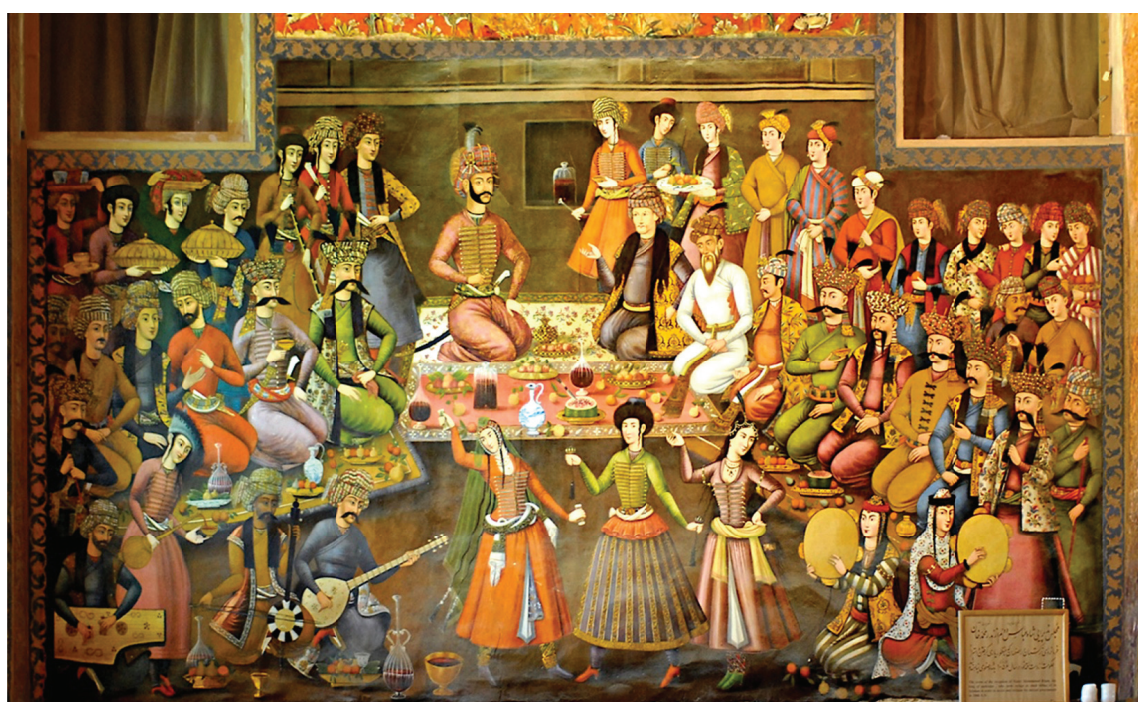

\section{3. Çihil Sütunun Avrupa Tarzı Resimleri}

Safevi döneminde Avrupa'dan gelenler (elçiler, tüccar, seyyah, doktor v.s) genelde başka bir amaç için İran'da bulunmaktadırlar. Büyük bir olasılıkla Şah Abbas'ın resim sevdası olması ve sanatçıları himaye altına alması yabancı ressamlara güzel bir çalışma ortamı yaratmıştır. Bu ortamda yapılan resimler ne yazık ki imzasız bırakılmıştır. Çihil Sütunun duvar resimlerinin çoğu imzasız olduğundan dolayı onların kime ait olduğu ve ayırt edilmesi mümkün olmayabilir ancak resimlerin tarz1 ve uslubu ile ressamlar1nın tahmin edilmesi mümkündür. Ayrıca Muhammed Zaman ve Ali Kulu Cebbadar'ın resimlerindeki üslubü da Avrupa ressamlarının çalışmalarına çok benzemektedir.

İran'ın resim sanatında gerçekçilik veya gerçekçiliğe benzeyen görünüş Avrupa sanat dünyasında Rönesans’tan itibaren başlamıştır. Bu tarzda resim yapmak Safevi'nin son yıllarında yayılmış ve Kaçar döneminde İran'ın resim sanatına hakim olmuştur. Kaçar'ın resimleri özellikle portre alanındaki benzersiz üslubu İran resim sanatında parlak bir dönem ortaya 
çıkarmıştır. Sonraki sayfalarda gösterilen resimler Avrupalı ressamlar tarafından çizilmiştir. Bu resimler eyvanın kuzey tarafında yer almaktadır (Res.25-34).

Çihil Sütun'da yabancı ressamlar tarafından çizilen duvar resimlerindeki süslemelerin kendine has olan özellikleri vardır. Birbirine uyumlu olan parlak ve tezat renklerin kullanılması, perspektifin olmayışı ve resimdeki uzaklık ve yakınlığın resmin planına göre ayarlanması en belirli özelliklerdir. Işık resmin her yönünde aynıdır. Resimlerdeki insan figürlerinin etrafı siyah çizgilerle belirtilmiştir. Figürlerin resimlerdeki yerlerindeki duruşları, elbiselerdeki desen değişikliği, tabiattan alınan şekiller (ağaç ve dağ v.s), nesneler, mimari tarz ve figürlerin İranlı veya yabancı oluşu gayet net ve güzel belli edilmiştir.

Resim 25: Çihil Sütun Sarayı, resim yazar tarafından çekilmiştir.

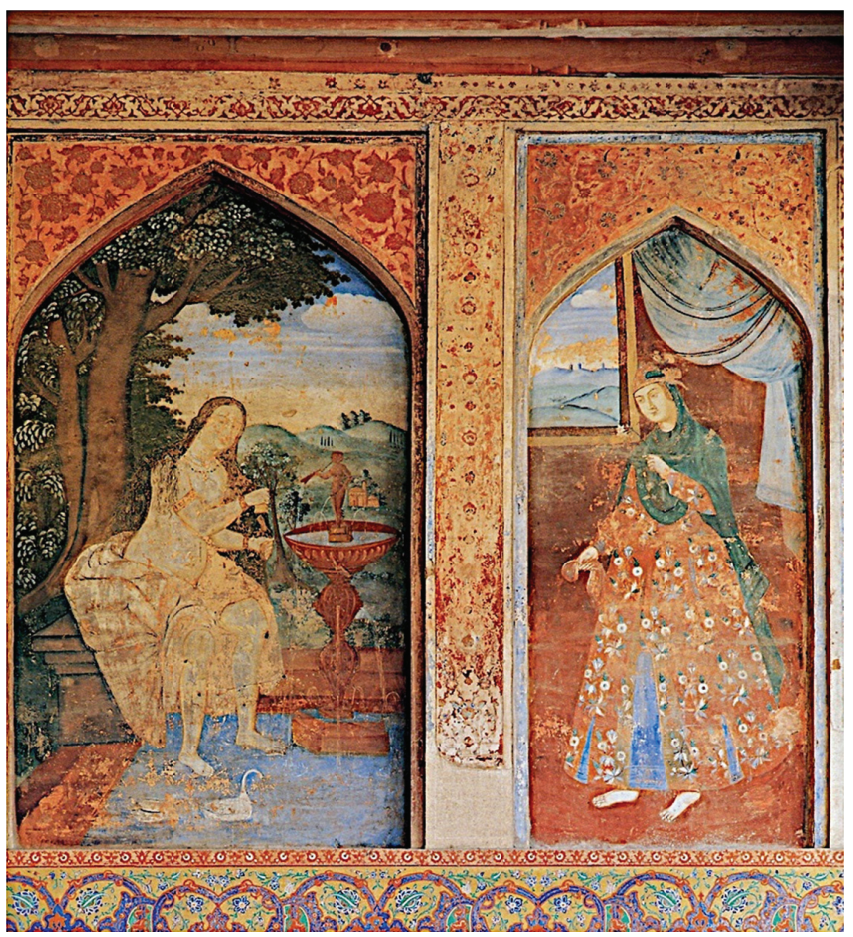


Resim 26-27: Çihil Sütun Sarayı, resim yazar tarafından çekilmiştir.

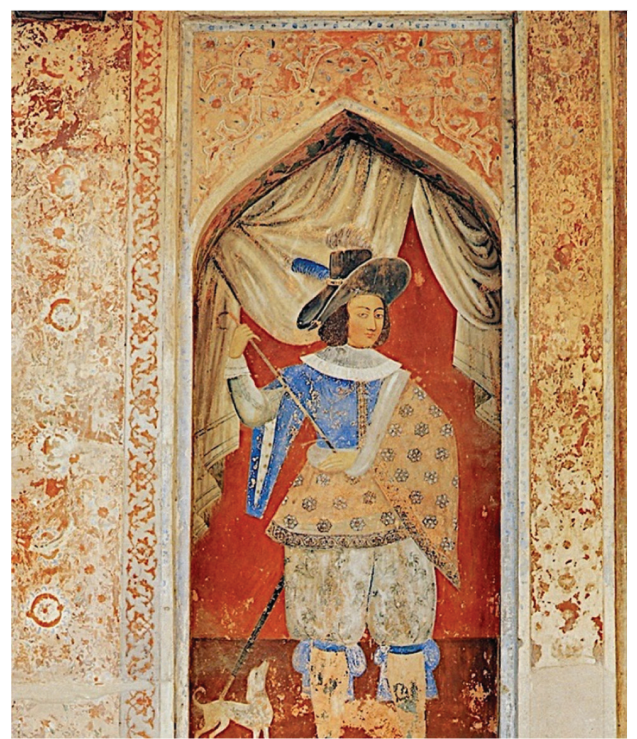

Resim 26

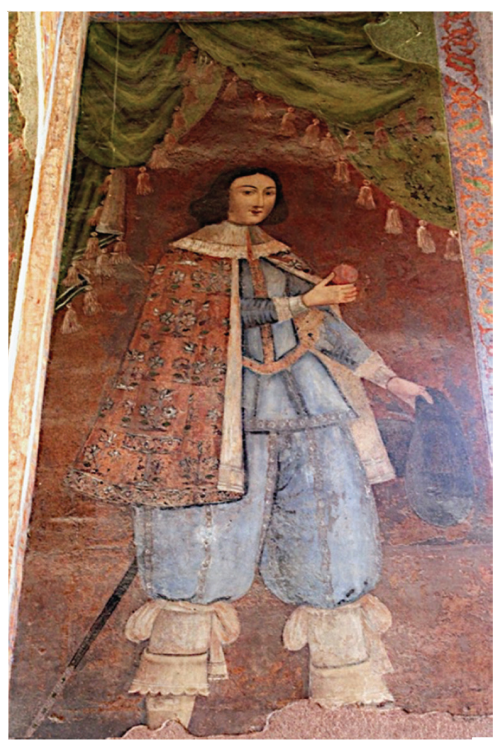

Resim 27

Resim 28-29: Çihil Sütun Sarayı, resim yazar tarafından çekilmiştir.

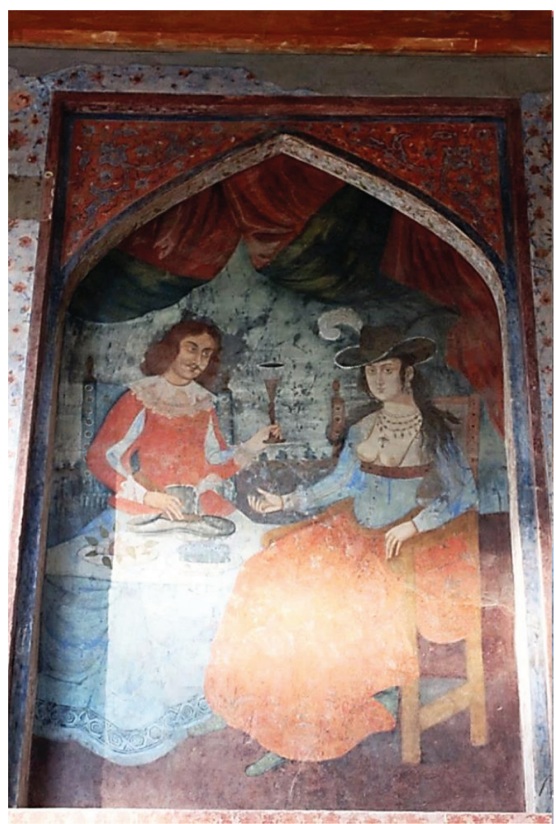

Resim 28

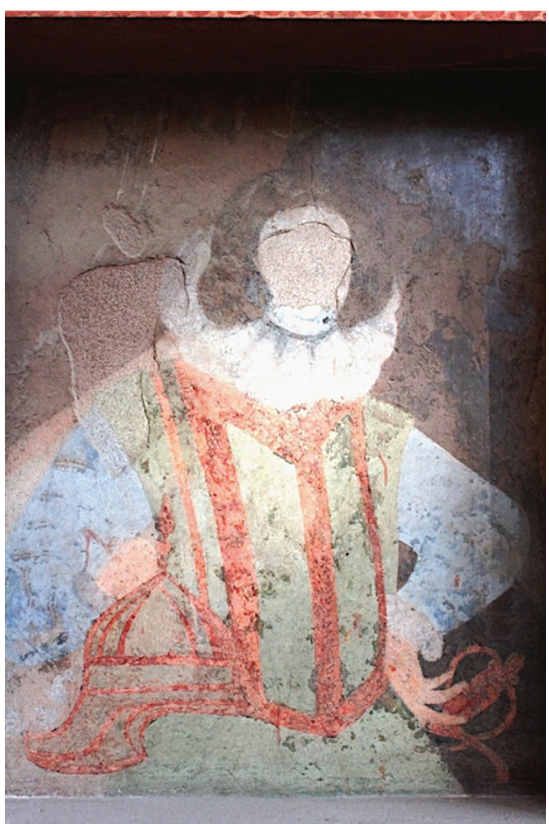

Resim 29 
Resim 30-32: Çihil Sütun sarayı, resim yazar tarafından çekilmiştir.

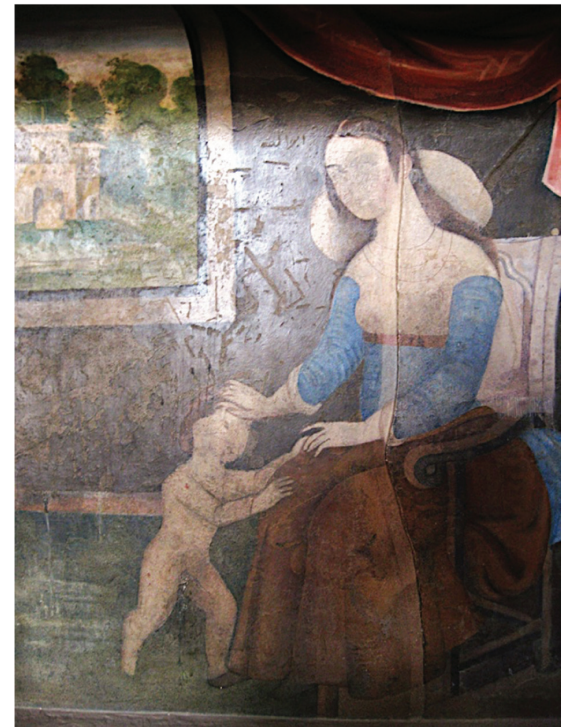

Resim 30

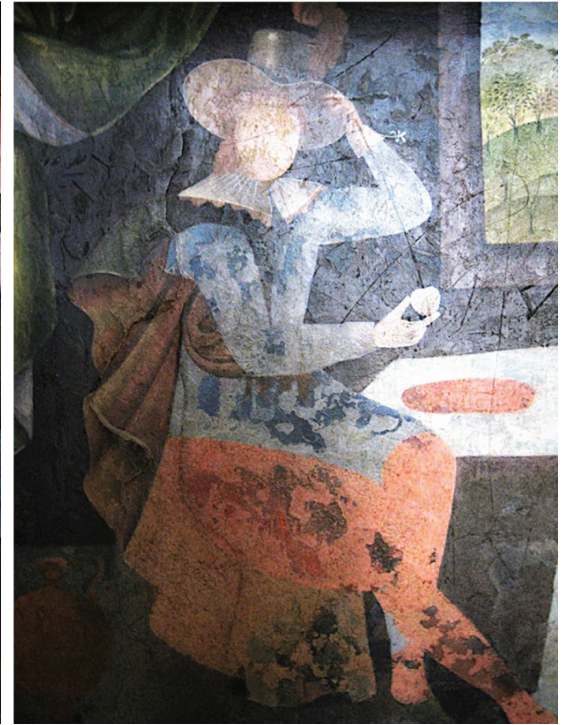

Resim 31

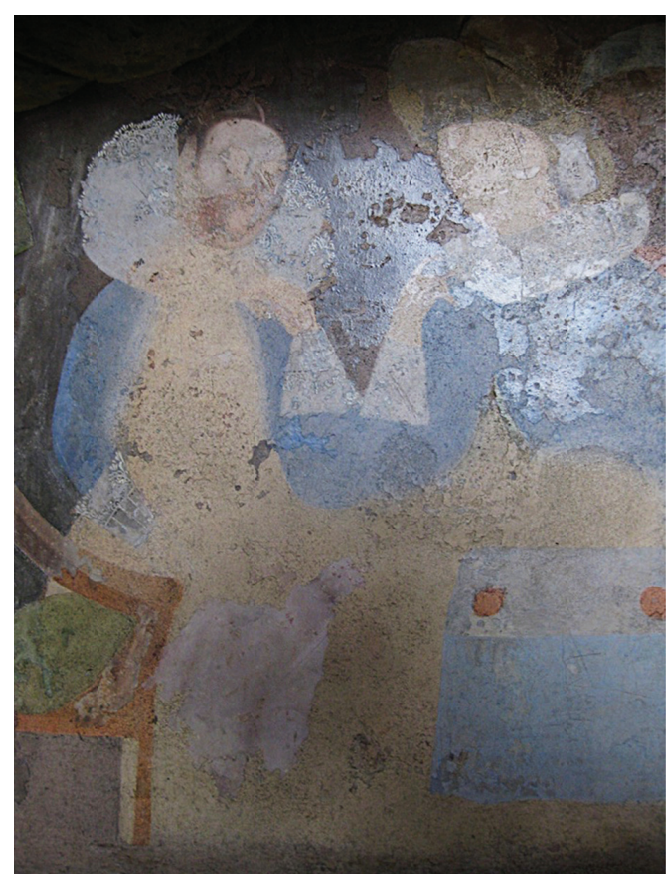

Resim 32 
Resim 33-34: Çihil Sütun sarayı, resim yazar tarafından çekilmiştir.

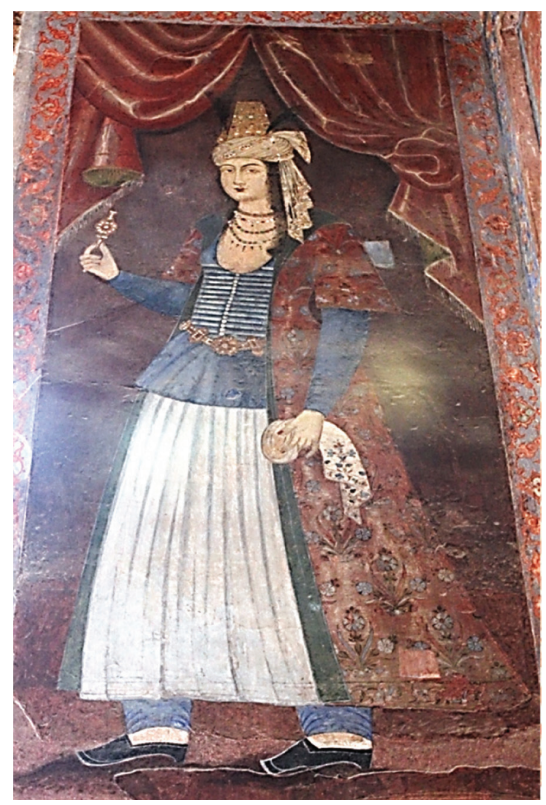

Resim 33

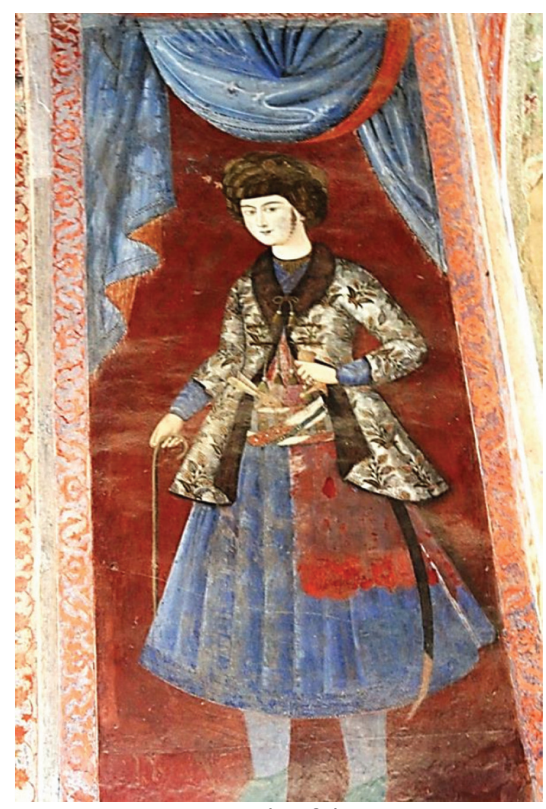

Resim 34

\section{4. Çihil Sütun'un Avrupa Duvar Resimleri'nin Estetik ve Teknik Özelliği}

Çihil Sütun'un duvar resimlerinin estetiğini inceleyecek olursak, bu resimlerde görselliğin yansıttı̆̆ güzelliğin yanı sıra, inançların, itikatların ve düşüncelerin daha geniş bir şekilde yer aldığını görürüz. Renklerin kullanımındaki maharet ve zerafet dikkat çekmektedir. Bu, İsfahan'daki I. Şah Abbas döneminde ve daha sonraki dönemlerde sanatçılara verilen önem ve değerden ileri gelmektedir. Bu durum sanatçıların bakış açılarının genişlemesine ve daha rahat bir şekilde çalışmalarına imkan vermiştir. İnsanın ruhuna hitap eden bu estetiğin sırrı da şüphesiz sanatçıların eserlerini yaratırken en ince detaylara dayanan ölçülü ve hesaplı bir şekilde hareket etmesinden doğmaktadır. Renklerin son derece uyumlu ve dikkatli bir şekilde titizlikle çizilen çizgileri, ton farklarındaki görülen incelikleri ve zerafeti gördüğümüzde o zamandan bu zamana kadar gelen bu tarihi sanata hayran olmamak mümkün değildir. 
Safevi dönemindeki duvar tasvirlerinde renkler çeşitli bol renkli (elvan) olup lacivert (Lapis-Lazo) ve altın sarısından fazlaca istifade edilmiştir. Bu renkler tasvirin alt yapısında kullanılan ana renklerdir. ${ }^{36}$

Yine bu dönemde duvar renklerindeki yağlı boya ve tempre aynı zamanda yağlı altın tekniğinden istifade edildiğini göstermektedir. Mum şeklinde yumurta sarısı ile hazırlanan tempre resim tekniği Avrupa'da sanatçılar tarafından sık sık kullanılmış bir resim tekniğidir. Tahtanın veya duvarın alt yapısına sürülerek kullanılıyordu. Tempre tekniği Safevi döneminde duvar resim sanatında yaygın bir şekilde kullanılmıştır.

Rıza Abbasi'nin mektebinde kullanılan renkler şunlardır;

Kimyasal olan renkler, karbonat, beyazkil, lacivert, mavi, bakır rengine kaçan mavi, içinde çam tozu bulunan mavi, yeşil, bakıra çalan yeşil (malakit), surenj tozu (portakal rengine bakar), şengerf (civa sülfürü), Rus yeşil (bakır ile henüz bilinmeyen bir asit karışımı), okra (sarı, kahverengi, kırmızı, maş rengi), zernik, gümüş varakı, altın varak, doğal ve kimyasal renklerle olan karışım; kermez cevheri (şeffaf kırmızı olup şengerf rengine bakır veya benzer, nil rengi veya indigu (Hintlilerden alınma bir renk).

Duvar resimlerindeki estetik özellikleri İsfahan üslubuna göre şunlardır:

- Düz, parlak ve birbirini tamamlayan tezat renkler.

- Perspektifin olmayışı, uzaklık ve yakınlığın planlanarak renklerin tonları ile ayarlanması.

- Boyutun (hacim) olmayış1.

- Iş1k ve gölgenin Avrupai bir tarzda oluşu.

- Şairane ve romantik sahnelerin çizilmesinin konuda ağırlıklı olması.

- İnsan figürlerinde ve diğer resimlerdeki detayların çok zarif ve dikkatlice gösterilmesi (saç, yüz, kaş, göz, el, dağ, ağaç, yeşillikler, elbise desenleri v.s).

- Resimlerdeki konunun bina ve diğer mimari unsurlarla harmoni teşkil etmesi.

Bu detayların tümü İsfahan mektebinin üslubu olarak kabul edilmiştir. ${ }^{37}$

Aghajani ve Javani, Divar negari-i asr-i safevi - Kakh-i Chehel Sutun, 15.

37 Aghajani ve Javani, Divar negari-i asr-i safevi - Kakh-i Chehel Sutun, 20. 
İran sanatının Şii felsefesi ve özellikle Mulla Sadra ve Şeyh Bahayi'nin görüşlerinin sanata yansıtılmasının yayılışı da bu devirde önemli bir yere sahip olmaktadır. Şii felsefine dair Çihil Sütun'un resimlerinde estetik bakımından şu ayrıntılar bulunmaktadır:

- Hayal imgesi/şüphe: bütün devirlerde en önemli bakış açısı olarak yer almaktadır.

- Yüzeysel hayal imgesi: dünyamız materyal özelliği ile öteki dünyayla temas kurmakta ve neticede yeni bir dünya yaratmaktadır.

- Kompozisiyon imgesi: soyutlandırılmış ve soyutlandırılmamış unsurlar birleştirilmiştir.

- Renk imgesi: harmonik ve yanardöner, zit renkler ile birlikte cennet gibi bir ortam yaratılmaktadır.

- İki yönlü imgesi: hayal ve belirsiz bir dünyada gerçekliğin olması ya da olmaması, figürün kişiliği ve cinsiyetinin belli olmaya çalışması, örneğin bazi figürlerin erkekliği ve kadınlığı belirginleştirilmemiştir. ${ }^{38}$

\section{Serder-ı Kayseriye ve Sokiyas Köşkünün Avrupa Tarzı Duvar Resimleri}

\subsection{Serder-1 Kayseriye}

Serder-1 Kayseriye yapıtı İsfahan Pazarının ana girişinde yer almaktadır. Serder-1 Kayseriye dört kapıdan ve bir ana giriş kısmından oluşmaktadır. Eski zamanlarda üç kattan (Üçüncü katı Nagar hane tahrib edilmiştir) oluşan yapının şimdiki hali ise iki katlıdır. Safevi döneminde müzik sesiyle buradan günün saati halka ilan ediliyordu. Bu yapit İsfahan'ın büyük pazarına açılmakta ve Safevi Devrinde pazarın ana yolu olarak kullanıyordu. Anadolu'daki Kayseri şehrinde bulunan bir binadan esinlenerek yaptırılıp zaman içinde de Serder-1 Kayseriye olarak adlandırılmıştır. Yapıtın giriş kısmında Riza Abbasi'nin resimleri ve bir Avrupa tarzı resim (Res. 35) yer almaktadır. ${ }^{39}$

Yapıtın çini süslemeleri, Şah Abbas'ın Özbeklerle savaşı, Avrupalı kadın

\footnotetext{
38 Aghajani ve Javani, Divar negari-i asr-i safevi - Kakh-i Chehel Sutun, 13.

39 "Fa," Wikipedia, Erişim Tarihi: Haziran 02, 2016, http://fa.wikipedia.org.
} 
ve erkekler imaji ile tasvir edilmiştir. Bir duvarında Avrupalı ressamlar sıva üzerine yağlı boya tekniği ile betimleme yapmışladır. ${ }^{40}$

Ressamı belli olmayan bu duvar resmi, zarif işlemeleri maharetli renk seçimi ve kalabalık bir kompozisyon içinde eğlence törenini göstermektedir. Resmin arka planında İsfahan'ın manzara ve şehir yapıtları dikkat çekicidir. Müzisyenler çalarken görünmekte, (Res. 36) bir terasta duran Avrupalı bir erkek ise yukardan o törene göz gezdirmektedir. Figürlerin kıyafetleri renk ve modeli (şapka, kolye, v.s) Elizabet döneminin moda tarzını andırmaktadır.

Resim 35: Serder-1 Kayseriye, resim yazar tarafından çekilmiştir.

Resim 36: Resim 38'in detayı, resim yazar tarafından çekilmiştir.

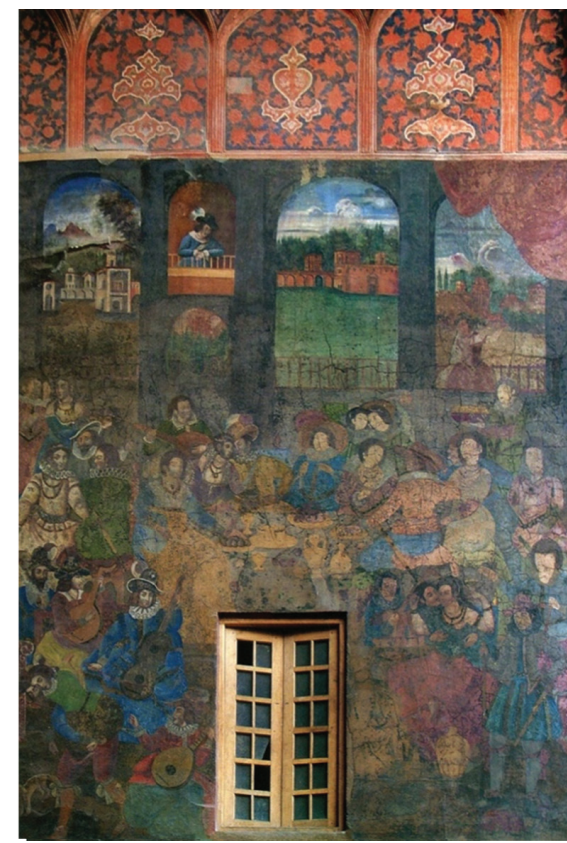

Resim 35

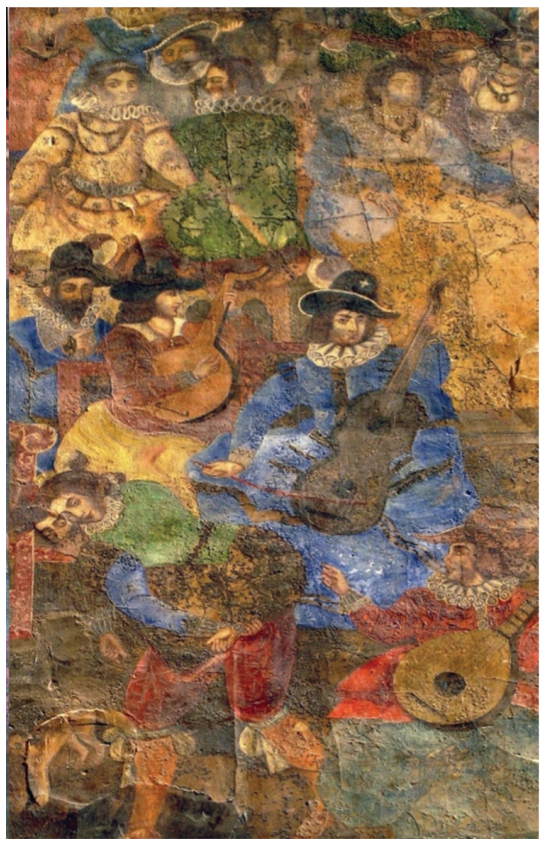

Resim 36

40 “İsfahan,” Wikipedia, Erişim Tarihi: Aralık 11, 2016, http://isfahan.ir. 


\subsection{Sokiyas Köşkü}

İsfahan'da bulunan Sokiyas köşkü (Colfa Mahallesinde) 2000 metre kare bir sahayı kaplayıp Safevi dönemine ait bir yapıdır. Safevi döneminin yaygın bir mimari tarzı ile iki bağın içinde yer almaktadır. Binanın kuzey tarafındaki Tebrizliler sokağının giriş kısmı mukarnas ile süslenmiştir. Taç kapısının yan tarafında da odalar bulunmaktadır. Ana bina dikkat çeken bir mimariye sahip olup (Res. 37) içindeki resimler altın ile işlenerek süslenmiştir. Binanın orta kısmında iki katlı bir salon, salonun ortasında da sekizgen bir havuz, yan taraflarında da revaklar yer almaktadır. Zemin katta bulunan revaklar ve oyukların içinde Safevi döneminden kalan resimler görünmektedir. Orada yapılmış olan resimler Rıza Abbasi’nin mektebine ait tarzıyla zarif işlemeleri ve güzelliği ile dikkat çekmektedir. ${ }^{41}$

Resim 37: Sokiyas Köşkü. Yapıtın ana girişi, Show Page, Isfahan, Google, Erişim Tarihi Şubat 24 2016, http://isfahan.ir/ShowPage/.

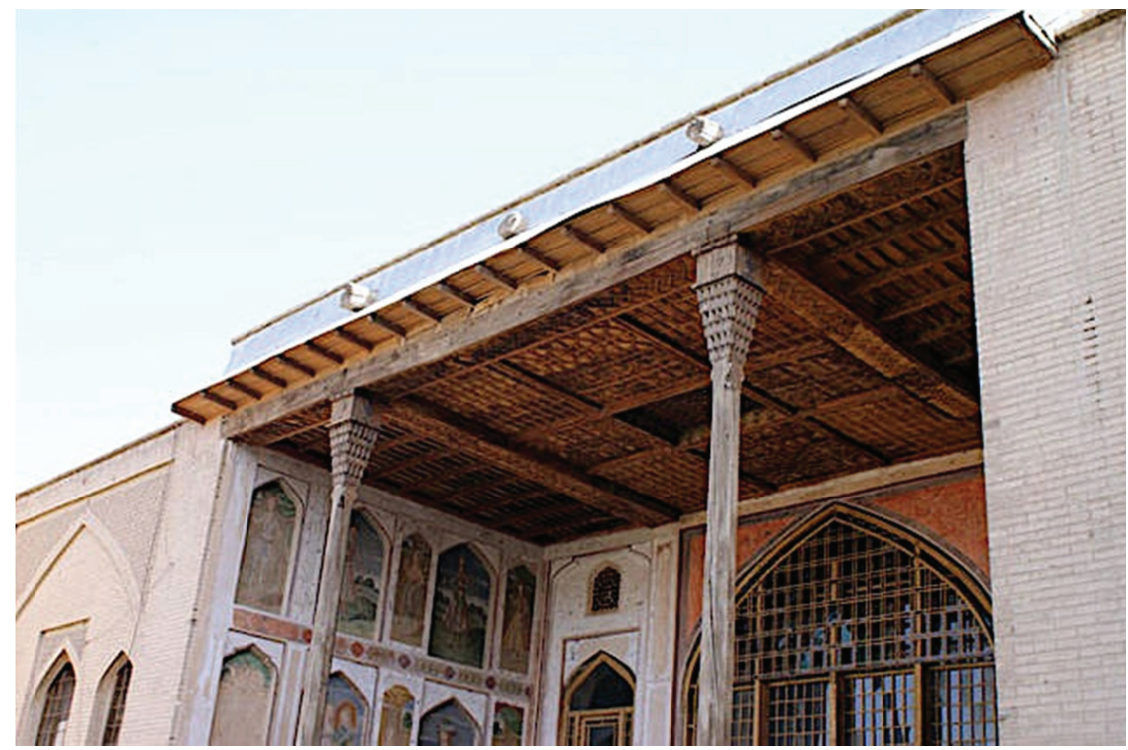

41 "Isfahan," Google Show Page, Erişim Tarihi: Şubat 24, 2016, http://isfahan.ir/ ShowPage/. 
Yapıtın kuzey eyvanı üç (orsi) pencerelerle ana salondan ayrılmaktadır. Eyvanın sağ ve sol tarafında çerçeve içinde batı tarzı ile portreler resimlendirilmiştir. Bu portrelerin ressamları belli değil ama büyük bir olasılıkla Minas (Ermeni) ressam veya Rıza Abbasi'nın öğrencileri tarafından tasvir edilmiştir (Res. 38-39-40). Resimlerin tarzı Şah Abbas döneminin resim üslubu ve yabancı ressamların işçiliğine benzemektedir (Res. 41).

Resim 38: Sokiyas Köşkü, Sağ duvardaki görüntüsü, resim yazar tarafindan çekilmiştir.

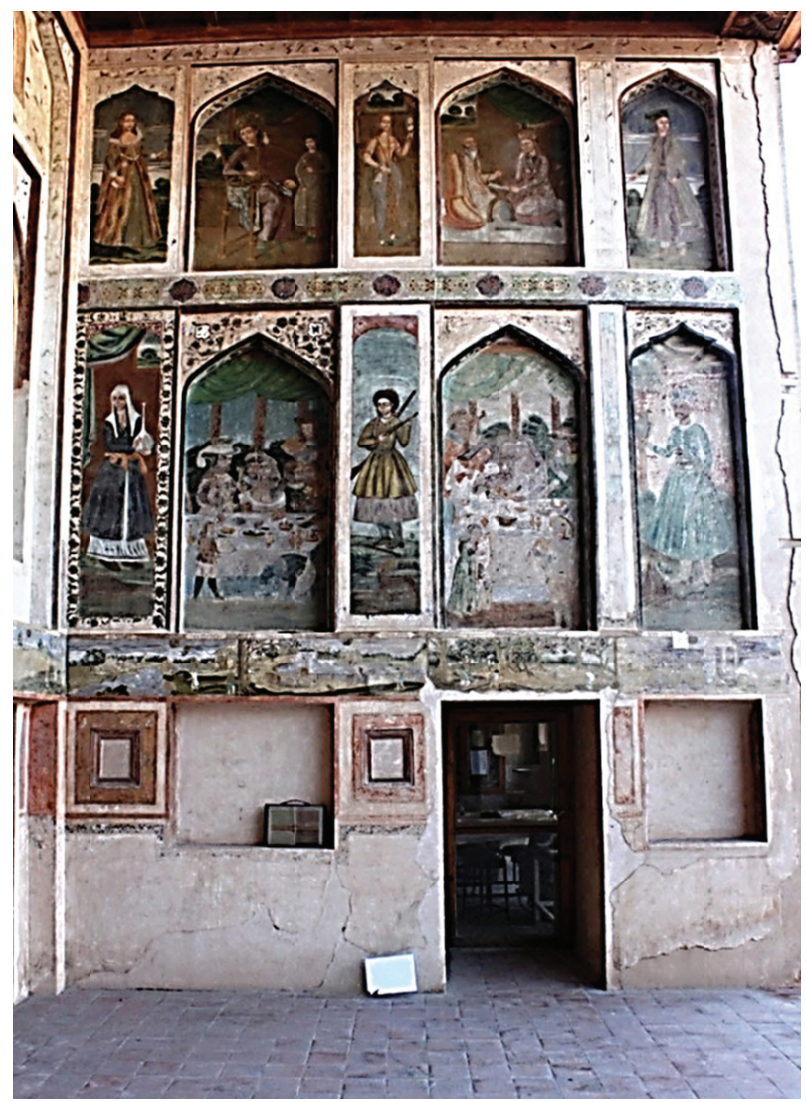


Resim 39: Sokiyas Köşkü, Sol duvardaki görüntüsü: çerçeve içinde portreler yer almaktadır, resim yazar tarafından çekilmiştir.

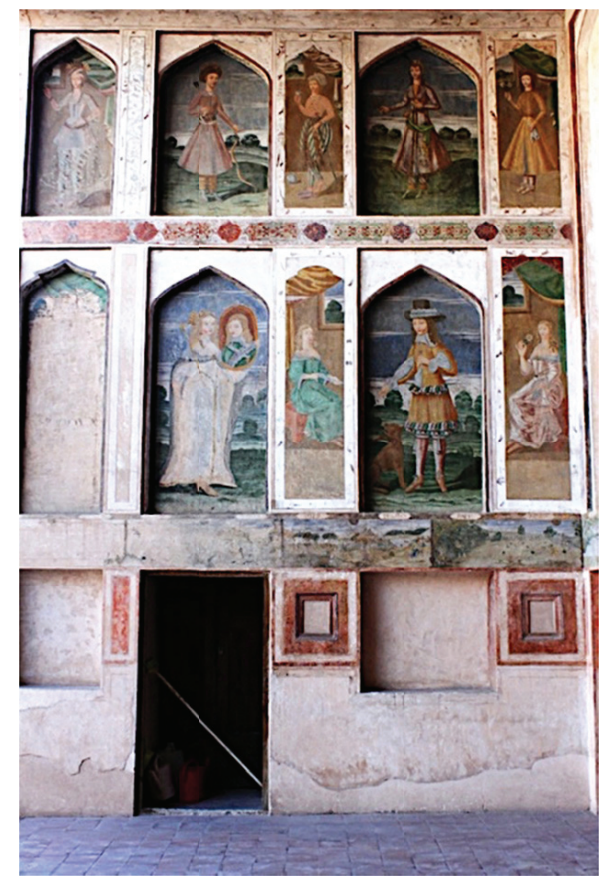

Resim 40: Sokiyas Köşkü, Sağ duvarındaki detayl görüntüsü: çerçeve içinde portreler yer almaktadır, resim yazar tarafından çekilmiştir.
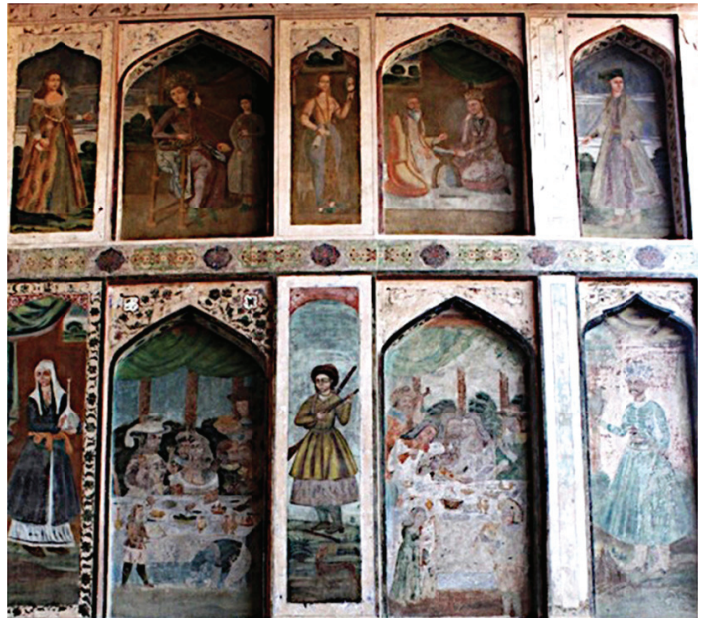
Resim 41: Sokiyas Köşkü, Sağ duvarındaki üst kısmında çerçeve içinde portreler yer almaktadır. En güzel portreler, zarif işlenmelere dikkat almaktadır. Resim yazar tarafından çekilmiştir.

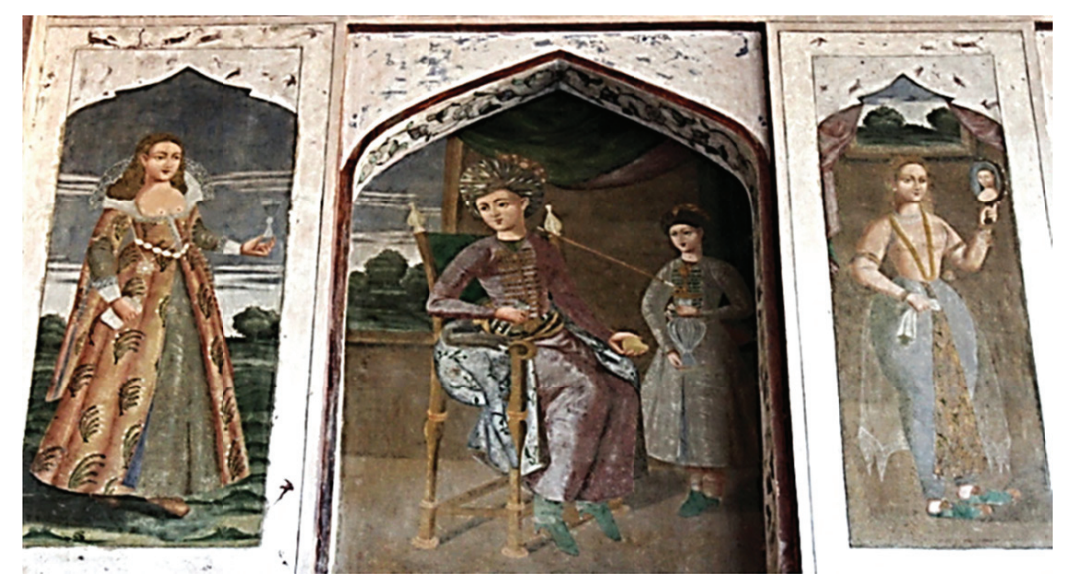

Portreler, Hiristiyan ailelerin yaşamı, eğlenceleri, avcılığı ve hatta eğitimini göstermektedir. Bu eyvanda 20 adet yer alan portre resimlerden biri zaman içinde veya çeşitli nedenlerle bozulmuştur (Res. 42). Resimlerin kenarları, eslimi ve hatayi (Arap motifleri) motiflerle süslenmiştir. Sokiyas Köşkü, mimari üstünlüğü harika süsleme ve işlemelerinden dolayı İran Devrimi'nden önce devlet tarafından sahiplerinden satın alınıp Farabi Üniversitesi’ne teslim edilmiştir. Şimdilik İsfahan Sanat Üniversitesi yapı restorasyon işlemini yapmaktadır. 
Resim 42: Sokiyas Köşkü, Sokiyas Köşkü, Sol duvarındaki detaylı görüntüsü: çerçeve içinde portreler yer almaktadır, resim yazar tarafından çekilmiştir.

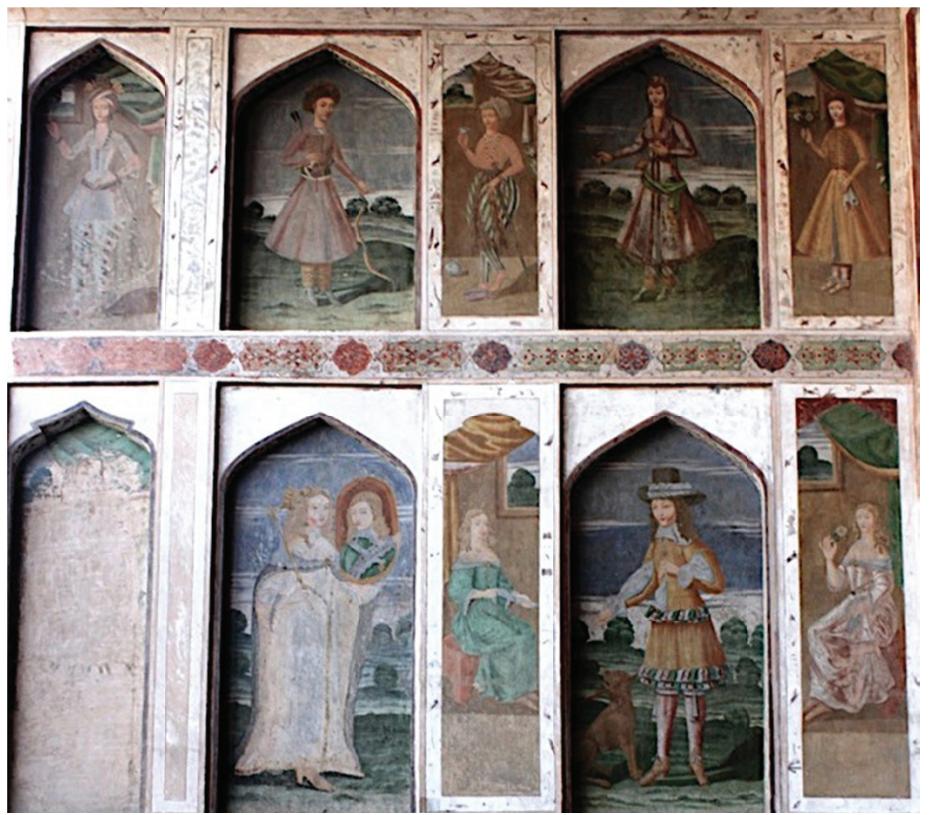

\section{Sonuç}

Safevilerin çağında İran; ticari, sanayi ve kültür bakımından dünyada bir egemenliğe sahip olmuştur. Safevilerin zenginlik ve ihtişam bakımından zirvede bulunduğu devrin temsilcisi Şah Abbas sayesinde ortaya çıkan yeni resim sanatı kimlik arayışı; zaman içinde İran/Avrupa karması bir resim üslubu oluşturmuştur. Bu yeni kimlik birleşiminde Safevilerin Avrupa kökenli olmamaları, 17. yüzyılın ikinci yarısı ve sonlarına doğru ortaya çıkan Muhammed Zaman, Ali Kulu Cebbedar, Bahram Sofrekeş gibi sanatçıların Avrupai tarzdaki resimlere hayran kalmalarının bu üslubun kabul görmesinde rolü büyüktür. İran'ın resim sanatında gerçekçilik veya gerçekçiliğe benzeyen görünüş Avrupa sanat dünyasında Rönesans’tan itibaren başlamıştır. Bu tarzda resim yapmak Safevinin son yıllarında yayılmış ve Kaçar döneminde İran'ın resim sanatına hakim olmuştur. Şah Abbas’ın resim sevdası ve sanatçıları himaye altına alması yabancı ressamlara da güzel bir çalışma ortamı yaratmıştır. Bu nedenle, Hristiyan Ermeniler, Hintli sanatçılar gibi yabancı uyruklu olan sanatçılar başka bir vazife veya amaç ile İran'da bulunurken ressamlık da yapmışlardır. 
$\mathrm{Bu}$ ortamda yapılan Avrupa tarzdaki resimler ne yazık ki imzasız bırakılmıştır. Safevi döneminin Avrupa tarzı duvar resimlerinin çoğu imzasız olduğundan dolayı onların kime ait olduğu ve ayırt edilmesi mümkün olmayabilir ancak resimlerin tarzı ve üslubu ile ressamlarının tahmin edilmesi mümkündür. Safevi dönemindeki Avrupa tarzı duvar resimlerinin çoğu Rönesans tarzı ile betimlenmiş fakat Avrupa resimleri ile kıyaslandığında daha basit ve tekniği daha yüzeysel gözükmektedir. Ancak ressamların çizdiği bu tür tasvirlere Avrupa resmi ile Doğu üslubunun (İran ve Hindistan resim üslupları) birleşimi ya da Safevi üslubu denilebilir.

\section{Kaynakça}

Aghajani A. ve Javani H. Divar negari-i asr-i safevi - Kakh-i Chehel Sutun. Tahran: Ferhengistan-i Honar, 2007.

Aydoğmuşoğlu, Cihat. “Şah Abbas (1587-1629) Devrinde İran'da sosyal ve Kültürel hayat." Türk Dünyası İncelemeleri Dergisi / Journal of Turkish World Studies XI, no. 2, (Nisan 2011): 261-270.

Babaie, S. Shah 'Abbas II, The Conquest of Qandahar, the Chihil Sutun and Its Wall Paintings, Muqarnas XI an Annual on Islamic Art and Architecture, Gülru Necipoglu (Ed.), Leiden: E.J. Brill, 1994.

Blair, Sheila. The Art and Architecture of Islam 1250-1800. New York: Yale University Press, 1997.

Canby, Sheila. Golden Age of Persian Art. London: British Museum Press, 2002.

Chardin, J. A. Journey to Persia. R.W. Ferrier (Ed.), London NewYork: I.B. Tauris Publication, 1996.

Diba, Layla ve S- Ekhtiar, Maryam. Royal Persian Painting: The ka Qajar Epoch 1785-1925, I. B. Tauris Publisher in association with Brooklyn Museum of Art, 1999.

Farhad, Massumeh. Searching for the New" Later safavid Painting and the Suz u Gawdaz (Burning and Melting) by Nau'i Khabushani. Freer Gallery of Art, Arthur M. Sackler Gallery, Smithsonian İnstitution, Washington, D. C, 2000 . 
Ferrante, M. Travaux de restauration de monuments historiques en İran, Zander G. (Ed.), Rome: IsMEO, 1968.

Hatam, Gholamali. Honar ve Temeddünü İslami. Tahran: Payam Nur Üneversitesi, (II cilt), 2005.

Honarfar, Lutfullah. Gencine-1 Asar-1 Tarih-1 İsfahan. Tahran: İsfahan Üniversitesi Yayınları, 1966.

Koch, E. Diwan-i 'Amm and Chihil Sutun the Audience Halls of Shah Jahan, In Muqarnas XI an Annual on Islamic Art and Architecture, Gülru Necipoglu (Ed.) Leiden E.J. Brill, 1994.

Piotrovsky, M.B. ve Rogers, J.M. Heaven on Earth- Art from İslamic Lands, Prestel Publisher, 2004.

Pirniya, Muhammet Karim. İran'nın mimari akımları. Tahran: Soruş daneş yayını, 2011.

Pope, A. U. ed. A Survey of Persian Art. 1-6. (london and New York: Oxford University Press, 1939), vol. 5, res. 554, A ve B.

Pope, Arthur Opham. Iran'nın sanat şaheserleri. Tahran: Elmi- Ferhengi (ilim-kültür) yayını, 2012.

Rostami, N. M. Memari-i İsfahan. Tahran: Vajehara, 2011.

Sattari, Jalal. "Alı Kapu duvar resimleri”, Honar va mardom (Sanat ve Toplum) dergisi, 6. Say1, (Aralık 1986): 63-78.

Soudavar, Abolala. Art of the Persian Courts: Selections from the Art and History Trust Collection, Rizzoli Publisher, 1992.

Sümer, Faruk. Safevi Devletinin kuruluşu ve Gelişmesinde Anadolu Türklerin Rolü. Ankara: Türk Tarih Kurumu, 1976.

Tal-berk, Frederic. Ez Körüş ta Pehlevi, Şiraz: Pehlevi Üniversitesi, 1968.

\section{İnternet Kaynakları}

Babaie, Sussan. "Shah Abbas II, the conquest of Qandahar, the Chihil Sutun, and its wall painting." Google. Şubat 1994, No.126, http://archnet.org/ library/documents/one-document.jsp?document_id=3695.

Google. "Haydar-mirza-safavi." iranicaonline, Erişim tarihi: Nisan 20, 2015. http://www.iranicaonline.org/articles/haydar-mirza-safavi. 
Google. "Archnet." Erişim tairihi: Nisan 17, 2017. http://archnet.org/library/documents/one-document.jsp?document_id=3695.

Google. "Christies." Erişim tarihi: Ekim 01, 2017. http://www.christies. com/lotfinder/drawings-watercolors/by-esaye-le-gillon-prague-datedsafar-5358843- details.aspx pos $=1 \&$ intObjectID $=5358843 \&$ sid $=\& p a$ $\mathrm{ge}=18$.

Google. "صفويان" Erişim tarihi: Ocak 01, 2018. http://fa.wikipedia.org/ wiki/صفويان.

Google. "Flicker." Erişim tarihi: Ağustos 26, 2016. http://www.flickr.com/ photos/youngrobv/1803476053/.

Google. "kousha Fotopages." Erişim tarihi: Kasım 17, 2015. http://kousha. fotopages.com/?entry=1949087.

Google. "iranpedia.ir." Erişim tarihi: February 09, 2016. http://iranpedia. ir/Attractions/index.php?bid=3155\&PageID=34733b1051f1 f214b81e186 cf9babc35.

Google. "iranziarat." Erişim tarihi: December 10, 2017. http://www.iranziarat.com/isfahan_2/chehel_sutun_2.html

Google. "isfahan.ir.” Erişim tarihi: Mart 16, 2018. http://isfahan.ir/ShowPage.aspx ?page $=$ form\&order $=$ show\&lang $=1 \&$ sub $=10 \&$ PageId $=86 \&$ cod $\mathrm{eV}=1$ \&tempname $=$ AsarTarikhy.

Google. "nisanet.” Erişim tarihi: Ekim 20, 2016. http://www.niasnet.org/ iran-history/artifacts-historical-places-of-iran/

Google. "Shahrmajazi." Erişim tarihi: Şubat 13, 2017. http://www.shahrmajazi.com/virtualcity-9449.xhtml.

Google. "Çehel Sütun.” Erişim tarihi: Ocak 26, 2015. http://tr.wikipedia. org/wiki/Çehel_Sütun.

Google. "Muhammet Zaman". Wikipedia, Erişim tarihi Mart 20, 2016. http://tr.wikipedia.org/wiki/Muhammet_Zaman.

Google. “Alikulu Cabbadar.” Wikipedia, Erişim tarihi Temmuz 02, 2014. http://tr.wikipedia.org/wiki/Alikulu_Cabbadar. 
